\title{
Database of petrophysical properties of the Mid-German Crystalline Rise
}

\author{
Sebastian Weinert ${ }^{1,2}$, Kristian Bär ${ }^{1}$, and Ingo Sass ${ }^{1,2}$ \\ ${ }^{1}$ Geothermal Science and Technology, Technical University of Darmstadt, 64287 Darmstadt, Germany \\ ${ }^{2}$ Darmstadt Graduate School of Excellence Energy Science and Engineering, \\ Technical University of Darmstadt, 64287 Darmstadt, Germany \\ Correspondence: Sebastian Weinert (weinert@geo.tu-darmstadt.de)
}

Received: 27 July 2020 - Discussion started: 2 September 2020

Revised: 10 December 2020 - Accepted: 12 February 2021 - Published: 1 April 2021

\begin{abstract}
Petrophysical properties are a key element for reservoir characterization but also for interpreting the results of various geophysical exploration methods or geophysical well logs. Furthermore, petrophysical properties are commonly used to populate numerical models and are often critically governing the model results. Despite the common need for detailed petrophysical properties, data are still very scarce and often not available for the area of interest. Furthermore, both the online research for published property measurements or compilations, as well as dedicated measurement campaigns of the selected properties, which require comprehensive laboratory equipment, can be very time-consuming and costly. To date, most published research results are often focused on a limited selection of parameters only, and hence researching various petrophysical properties, needed to account for the thermal-hydraulic-mechanical behaviour of selected rock types or reservoir settings, can be very laborious.

Since for deep geothermal energy in central Europe, the majority of the geothermal potential or resource is assigned to the crystalline basement, a comprehensive database of petrophysical properties comprising rock densities, porosity, rock matrix permeability, thermal properties (thermal conductivity and diffusivity, specific heat capacity) as well as rock mechanical properties as compressional and shear wave velocities, unconfined compressive strength, Young's modulus, Poisson's ratio, tensile strength and triaxial shear strength was compiled from measurements conducted at the HydroThermikum lab facilities of the Technical University of Darmstadt.

Analysed samples were mostly derived from abandoned or active quarries and natural or artificial outcrops such as road cuts, riverbanks or steep hillslopes. Furthermore, samples of the cored deep wells Worms 3 (samples from 2175-2195 m), Stockstadt 33R (samples from 2245-2267 m), Weiterstadt 1 (samples from 2502-2504 m), Tiefbohrung Groß-Umstadt/Heubach, B/89-B02 and the cored shallow wells (Forschungsbohrung Messel GA 1 and 2) as well as GWM17 Zwingenberg, GWM1A Zwingenberg, Langenthal BK2/05, EWS267/1 Heubach, and archive samples of the Institut für Steinkonservierung e.V. in Mainz originating from a comprehensive large-scale sampling campaign in 2007 were investigated.

The database (Weinert et al., 2020b; https://doi.org/10.25534/tudatalib-278) aims to provide easily accessible petrophysical properties of the Mid-German Crystalline Rise, measured on 224 locations in Bavaria, Hessen, Rhineland-Palatinate and Thuringia and comprising 26951 single data points. Each data point is addressed with the respective metadata such as the sample identifier, sampling location, petrography and, if applicable, stratigraphy and sampling depth (in the case of well samples).
\end{abstract}




\section{Introduction}

For geothermal energy, reservoir exploration often lacks dedicated slim-hole exploration wells to enhance the understanding of the physical and hydraulic behaviour of the explored geothermal reservoir at an early project stage (Sass et al., 2016). Therefore, reservoir characterization often solely relies on either geophysical exploration or numerical models which, in turn, need petrophysical input parameters to be successful and accurate. Due to the sparseness of reservoir samples, explained by the high costs of coring deep wells, petrophysical properties can be derived from outcrop analogue studies (e.g. Howell et al., 2014; Ukar et al., 2019) or literature data for suitable rock types (Bär et al., 2020). Nonetheless, even in rather isotropic, homogeneous material such as crystalline rocks, petrophysical properties can vary depending on their geochemical composition and texture (e.g. dataset of Krietsch et al., 2018, and references therein, Weinert et al., 2020a) but also physical appearance, microfractures or porosity (e.g. Mielke et al., 2017; Weinert et al., 2020a) as well as degree of alteration or weathering (e.g. Machek et al., 2013).

A profound understanding of the regarded rock type, its respective petrophysical properties and the methods for how those were measured is essential for populating numerical simulations or interpreting geophysical exploration methods. Despite the importance of petrophysical properties, as well as the importance of crystalline basement rocks in deep geothermal energy, to which $85 \%$ to $90 \%$ of the German geothermal potential is accredited (Deutscher Bundestag, 2003), such data are often either unpublished, only published for confined areas (e.g. Mielke et al., 2016; Aretz et al., 2016; Weydt et al., 2021; Weinert et al., 2020a) or published without important meta information. The search for suitable petrophysical properties can therefore be very time-consuming, and often only widely averaged properties can be found and are commonly used neglecting local heterogeneities, vertical and lateral variability and anisotropic behaviour of the rocks.

To overcome the lack of suitable petrophysical data, a sampling and measuring campaign was initiated within the scope of the Hessen 3D 2.0 project: "3D-Modell der petrothermalen und mitteltiefen Potenziale zur Wärmenutzung und -speicherung von Hessen" (Federal Ministry for Economic Affairs and Energy; funding no. 0325944A) with the aim to develop a comprehensive database. This database of petrophysical properties of the Mid-German Crystalline Rise was supplemented and compiled to facilitate easy access to research data on measured petrophysical properties and to allow for an adequate generalization for specific petrological units within the Mid-German Crystalline Rise. Therefore, the database presented here (Weinert et al., 2020b; https://doi.org/10.25534/tudatalib-278) publicly provides all relevant laboratory measurements on the Mid-German Crystalline Rise samples of a variety of unpublished and pub- lished studies of the Technical University of Darmstadt, as well as over 1900 newly measured data points.

\section{Mid-German Crystalline Rise}

The Mid-German Crystalline Rise (MGCR) is a NE-SWstriking Variscan complex of approximately $50-65 \mathrm{~km}$ width in the NW-SE extension and a length of several hundred kilometres along strike. Locally exposed in the Palatinate Forest, Odenwald, Spessart, Ruhla Mountains and Kyffhäuser Crystalline Complex, the MGCR is sandwiched between the Saxothuringian Zone to the SW and the Northern Phyllite Zone, which represents the southern suture zone of the Rhenohercynian belt to the NE (Fig. 1).

While the NW boundary between the MGCR and Northern Phyllite Zone is not exposed, the MGCR is fault bounded to the Saxothuringian Zone (Linnemann et al., 2008) to the SE.

The MGCR metamorphic and crystalline complexes are interpreted as the northern margin of Armorica (McCann et al., 2008) and hence a suture of the Rheic Ocean at the rim of the Bohemian Massif (Linnemann et al., 2008).

Outcrops of the MGCR display a variety of high-grade metamorphic Late Ordovician to Early Devonian rocks in the Böllsteiner Odenwald (450 Ma; Reischmann et al., 2001), the Spessart Crystalline Complex (418-407 Ma; Lippolt, 1986; Dombrowsky et al., 1995) or the Ruhla Crystalline Complex (413-400 Ma; Brätz, 2000; Zeh and Wunderlich, 2003). Mafic, intermediate and acid intrusive igneous rocks are preferentially exposed in the Bergsträsser Odenwald where they comprise up to $90 \%$ of the exposed rocks (Stein, 2001), as well as in Spessart and the Ruhla Mountains. The northern part of the Odenwald (Frankenstein Complex) is predominantly comprised of Late Devonian gabbro (362 $\pm 7 \mathrm{Ma}$; Kirsch et al., 1988) as well as metamorphic rocks. The southern part is composed of amphibolite-facies metamorphosed metasediments and gneiss (342-332 Ma; Todt et al., 1995), which were intruded by the undeformed Weschnitz, Tromm and Heidelberg plutons. Those intrusions are homogenous and comprised of monzodiorite to granodiorite (Weschnitz pluton), granite (Tromm pluton) and gabbro to diorite with later granite and granodiorite intrusions at the Heidelberg pluton (Timmerman, 2008). Post-tectonic carboniferous diorite and granodiorite dominate the SE part of the Spessart Crystalline Complex (approximately $330 \mathrm{Ma}$; Anthes and Reischmann, 2001), while carboniferous granites predominantly occur in the Ruhla Mountains (Timmerman, 2008).

\section{Contents and structure of the database}

The database is provided in spreadsheet format as well as in a delimited text file format. It is structured in two superentities, namely "metadata" and "petrophysical properties", and further hierarchical structured into logical subdivisions. 


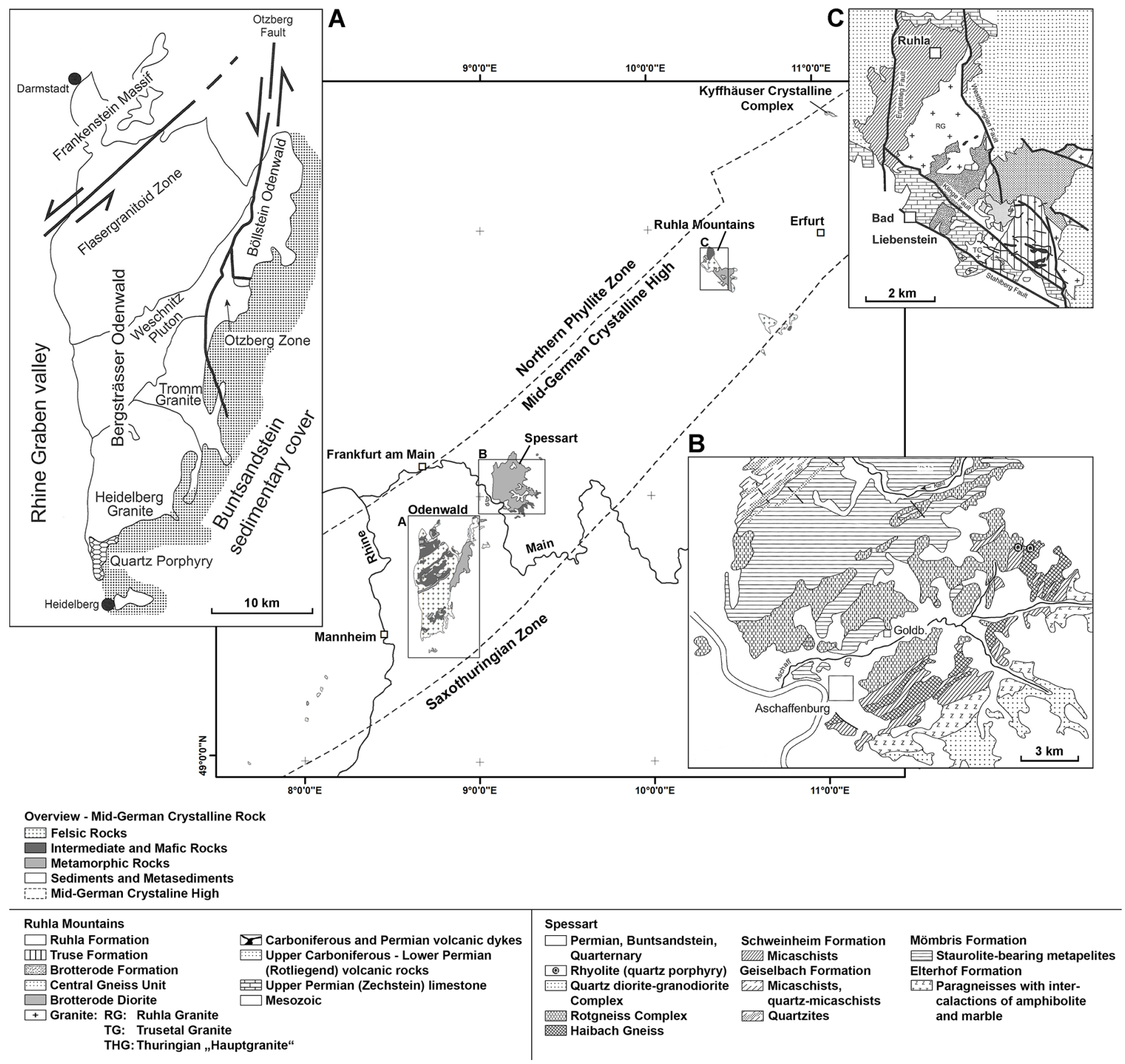

Figure 1. Simplified overview map (after Hirschmann, 1995; Voges et al., 1993; Klügel, 1997; Kroner et al., 2008) of the Mid-German Crystalline Rise outcrops: (a) Odenwald (after Stein, 2001; Will and Schmädicke, 2001; McCann et al., 2008), (b) Spessart (after Okrusch, 1983; Dombrowski et al., 1995; McCann et al., 2008) and (c) the Ruhla Mountains (Zeh et al., 2003; McCann et al., 2008).

While the metadata store information about the sample location, sample ID and stratigraphic and petrographic information, the actual measured petrophysical properties are summarized under petrophysical properties.

Each super-entity and its content are described in following subchapters in detail.

\subsection{Metadata}

The "metadata" super-entity comprises information concerning the sample identifier (sample ID) and its parent ID, the analyser of the petrophysical properties, the sampling location and stratigraphic and petrographic information and the sample dimensions if measured and documented.

\subsubsection{Sample information}

The presented database renounces to unify sample IDs as other researches did (e.g. Bär et al., 2020) and instead only documents the original sample ID that was chosen by the analyser. If multiple measurements were performed on a single sample (e.g. thermal conductivity on top and bottom end 
faces of cylindrical samples), the parental sample ID of the actual specimen is also provided. Therefore, reviewing original sources is feasible and allows to easily search for samples and further information such as detailed descriptions in the original sources. For all data extracted from either published or unpublished theses or reports, the referring reference is also given and indexed in the bibliography of both the database (Weinert et al., 2020b) as well as the here-presented work.

Although all the presented data were analysed in the same institution by applying the same laboratory equipment, the individual person analysing the samples might affect the data during data gathering and results' evaluation (for example, picking shear wave velocities). While comparing datasets of different people, slight variations can occur. Therefore, the name of the person who has analysed the samples is also stored in the sample information.

\subsubsection{Sampling location}

Samples were taken from quarries, abandoned quarries, outcrops and wells (cored borehole sections) as well as the archive of the Institut für Steinkonservierung e.V. Knowledge of the sample origin is important in data evaluation. For example, samples taken in active quarries might be influenced due to excavation either by heavy machinery or explosives, while samples from abandoned quarries and natural outcrops may be slightly to significantly weathered. Well samples were subdued to higher temperature and pressure conditions and might show extension (micro)fractures due to stress relief during core retrieval ("core disking").

In addition to the outcrop type, information about the geographical origin of the sample is given by a location as well as the referring federal state and state of this location (e.g. location: east of Wingertsstraße, Alzenau; federal state: Hessen; country: Germany). Also, the location coordinates are indexed in the database and catalogued as decimal degree with the reference system WGS84. The elevation at the coordinate point is given in metres above mean sea level ( $\mathrm{m}$ a.m.s.l.).

For well samples besides geographical information, also the well name and its respective archive number (if applicable) are indexed. The given elevation correlates with the well head elevation and the depth of the sample conforms to the measured depth (MD) below ground level (b.g.l.).

\subsubsection{Stratigraphy}

The stratigraphy documented in the database is divided into the period and series representing the sample. Additionally, a term for the formation or unit is given, which, if given, conforms with the locally used term.

According to international standards, the documented terms used for the stratigraphic period and series correspond to the international chronostratigraphic chart of the International Union of Geological Sciences (IUGS) v2020/01
(Cohen et al., 2013, updated). For each stratigraphic period and series, a respective stratigraphic ID is provided which correlates with the stratigraphic IDs published in Bär and Mielke (2019), Bär et al. (2020).

\subsubsection{Petrography}

Petrographic metadata are given by a simplified petrographic term and a correlating petrographic ID and petrographic parent ID (Fig. 2). The petrographic IDs correspond to Bär et al. (2019), which is based on the well database of the Hessian Agency for Nature Conservation, Environment and Geology. Also, based on the petrographic ID presented in Bär et al. (2019), a parental petrographic ID for each sample is provided. Petrography is either evaluated microscopically on thin sections (if applicable) or macroscopically on fresh hand pieces.

\subsubsection{Sample dimensions}

If measured, the sample height and diameter are reported in centimetres $(\mathrm{cm})$. Additionally, the grain and bulk volume are documented in cubic centimetres $\left(\mathrm{cm}^{3}\right)$, and sample weight is reported in grams $(\mathrm{g})$.

\subsection{Petrophysical properties}

The database presented here includes 20 kinds of petrophysical properties measured on a variety of samples. To increase readability, petrophysical properties are subdivided into thermophysical and rock mechanical properties (Tables 1 and 2). All analyses performed on the same specimen are documented in the same row. For some methods such as thermal conductivity and diffusivity, multiple measurements at the identical sample are possible (e.g. top and bottom end faces on the sample). In the case of multiple measurements, each single measurement is documented in a separate row (sample ID). Additionally, an average value and standard deviation is given for the specimen (parental sample ID).

\subsubsection{Thermophysical properties}

Documented thermophysical properties include grain and bulk density, porosity, thermal conductivity and diffusivity, specific heat capacity and apparent and intrinsic permeability. Since thermal conductivity and thermal diffusivity are often measured on multiple surfaces, both parameters have three dedicated rows each. One row documents single measurements, one row documents the average value of the sample, and the last row documents the standard deviation of the average.

The total numbers of single thermophysical property measurements and average values are listed in Table 1.

All measurements were conducted at the Technical University of Darmstadt and the applied methods are described in the following section. 

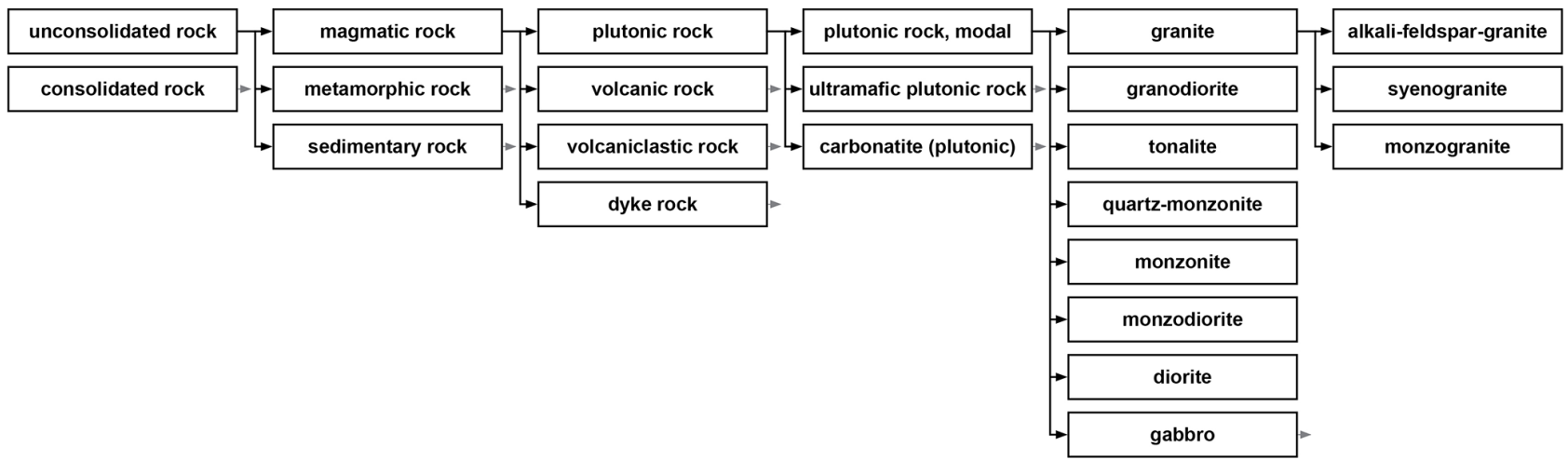

Figure 2. Hierarchical system of standardized petrographic terms referring to Bär et al. (2019). Black boxes show the rank and number of entries within each rank; white boxes represent the specific term and show classification scheme on the example of granites. Black arrows indicate direct connections and grey arrows represent additional terms not displayed here.

Table 1. Number of measurements of thermophysical properties.

\begin{tabular}{lll}
\hline Property & $\begin{array}{l}\text { Number of single } \\
\text { measurements }\end{array}$ & $\begin{array}{l}\text { Number of } \\
\text { measured } \\
\text { samples }\end{array}$ \\
\hline Bulk density & 974 & 974 \\
Grain density & 1238 & 1238 \\
Porosity & 918 & 918 \\
Thermal conductivity & 3518 & 1551 \\
Thermal diffusivity & 3298 & 1512 \\
Specific heat capacity & 1415 & 1415 \\
Apparent and intrinsic permeability & 991 & 991 \\
\hline Total & 12353 & 8600 \\
\hline
\end{tabular}

\subsubsection{Rock mechanical properties}

Compressional and shear wave velocity, dynamic and static Young modulus, dynamic and static Poisson ratio, unconfined compressive strength, bulk modulus and tensile strength as well as triaxial shear strength, cohesion and angle of friction are summarized (Table 2). Compressional and shear wave velocities are often measured multiple times on the same specimen; therefore, each single measurement is listed as well as the respective sample average including the standard deviation. Since a dynamic Young modulus and Poisson ratio are calculated using the compressive and shear strength, a sample average and standard deviation is also provided for them.

As for the petrophysical properties, all measurements were conducted at the Technical University of Darmstadt and the applied methods are described in the following section.
Table 2. Number of measurements of rock mechanical properties.

\begin{tabular}{lll}
\hline Property & $\begin{array}{l}\text { Number of single } \\
\text { measurements }\end{array}$ & $\begin{array}{l}\text { Number of } \\
\text { measured } \\
\text { samples }\end{array}$ \\
\hline Compressional wave velocity & 1247 & 822 \\
Shear wave velocity & 1247 & 822 \\
Dynamic Young modulus & 1165 & 740 \\
Dynamic Poisson ratio & 1247 & 822 \\
Unconfined compressive strength & 400 & 400 \\
Static Young modulus & 185 & 185 \\
Static Poisson ratio & 180 & 180 \\
Bulk modulus & 116 & 116 \\
Tensile strength & 231 & 231 \\
Triaxial shear strength & 106 & 106 \\
\hline Total & 5816 & 4116 \\
\hline
\end{tabular}

\section{Methods}

Measurements comprise grain density, bulk density, porosity, apparent and intrinsic permeability, thermal conductivity, thermal diffusivity as well as compressional and shear wave velocities, and at selected locations unconfined compressive strength, Young's modulus, Poisson's ratio, tensile strength, and triaxial shear strength including cohesion and coefficient of friction.

Prior to any measurement, samples were preferably cut to plugs of $40 \mathrm{~mm}$ diameter and $30 \mathrm{~mm}$ length and in the case of rock mechanical tests to cores of a length-to-diameter ratio of $2: 1$ at diameters of 64 and $55 \mathrm{~mm}$, and the core end faces were ground parallel and perpendicular to the core axis. Tensile strength analyses were performed on disks with a heightto-diameter ratio of $1: 2$ at diameters of 64 and $55 \mathrm{~mm}$. However, some analyses were also performed on different sample dimensions if the method allowed. 
All measurements were conducted on oven-dry specimens at laboratory conditions of an average atmospheric pressure of about $0.1 \mathrm{MPa}$ and at $20^{\circ} \mathrm{C}$ for thermal rock properties and at approximately $23^{\circ} \mathrm{C}$ for other petrophysical properties. The samples were dried in a conventional oven at 105 or $60^{\circ} \mathrm{C}$ (depending on the samples' clay content) until constant weight.

As follows, all applied methods are briefly described. For a more detailed methodological description, please refer to Weydt et al. (2021).

\subsection{Thermophysical properties}

Grain (skeletal) density was determined in a gas expansion pycnometer (AccuPyc II 1340) by applying helium as a displacement fluid. The accuracy for grain density measurements is stated by the manufacturer as $0.02 \%$. Each data point is sampled from five single measurements. Bulk density measurements are measured with an envelope density analyser (GeoPyc 1360). A well-sorted, fine-grained powder (DRY-FLO) is utilized as displacement material to determine the bulk volume of the specimen. Based on the bulk volume and weight of the specimen, bulk density is calculated, which then, together with the grain density, is used for the calculation of the specimen's gas effective (or connective) porosity. The accuracy is given by the manufacturer to be within $1.1 \%$. Measurements comprise three single measurements which have been averaged. Negative porosity values are reported on very low porous samples but should be seen as samples with $>1.1 \%$ porosity.

Dry bulk thermal conductivity and thermal diffusivity were measured using a commercial thermal conductivity scanner (Lippmann and Rauen TCS) by applying the optical scanning method after Popov et al. (1999). Both parameters are measured by temperature sensors mounted on a slide moving beneath a sampling area along the core axis. For the thermal conductivity, samples and a pair of references are heated up by approximately $4{ }^{\circ} \mathrm{C}$ in comparison to the ambient temperature. Thermal diffusivity is determined almost equally, except that the temperature is additionally measured with a third temperature sensor shifted $7 \mathrm{~mm}$ perpendicular to the axis of movement. During scanning, every $1 \mathrm{~mm}$, a single measuring point is logged, and at each logging point thermal diffusivity and conductivity are calculated based on the subsequent heating rate. The manufacturer states an accuracy within $3 \%$ of the thermal conductivity and $5 \%$ of the thermal diffusivity measurement.

Specific heat capacities are calculated after Buntebarth (1984):

$c_{p}=\frac{\lambda}{\rho_{\mathrm{bulk}} \cdot \kappa}$,

where $c_{p}$ is the specific heat capacity, $\lambda$ is the thermal conductivity, $\rho_{\text {bulk }}$ is the bulk density, and $\kappa$ is the thermal diffusivity.
The intrinsic permeability was measured based on the principle of Klinkenberg (1941) using a column gas permeameter, which measures the permeability of plugs applying a pressure gradient between the top and bottom surfaces of the sample mounted in a Hassler cell (Filomena et al., 2014). The sample's sidewall is sealed by a rubber sleeve and an applied confining air pressure to prevent leakage. Since the intrinsic permeability reflects the effective gas permeability under infinite pressure, the intrinsic permeability is, if necessary, extrapolated based on the Klinkenberg plot of multiple single measurements of at least five different injection pressure levels at constant pressure gradients.

Apparent permeability is measured with a mini permeameter, which measures the permeability at various injection rates in the near-field area of a nozzle, pressed against the sample surface. Like the column permeameter, the mini permeameter utilizes air as a measuring medium. The detection limit is $1 \times 10^{-18} \mathrm{~m}^{2}$, and it also needs to be addressed that apparent permeability measurements with the mini permeameter tend to overestimate matrix permeability in lowpermeable rocks.

\subsection{Rock mechanical properties}

Ultrasound wave velocities were measured using the Geotron USG 40 commercial ultrasound generator with mounted UPE-S (receiver) and UPG-S (emitter) probes, which enhance the shear wave signature. Both probes are pressed against the centre of each end surface of the specimen. The contact pressure was set to $0.1 \mathrm{MPa}$ and a shear gel (Magnaflux 54-T04) was applied between sample and probe to enhance the transmission of shear waves.

Dynamic elastic parameters are calculated with the equations

$$
\begin{aligned}
& v_{\text {dyn }}=\frac{V_{\mathrm{p}}^{2}-2 V_{\mathrm{s}}^{2}}{2\left(V_{\mathrm{p}}^{2}-V_{\mathrm{s}}^{2}\right)} \\
& E_{\text {dyn }}=\rho_{\text {bulk }} V_{\mathrm{p}}^{2} \frac{\left(3 V_{\mathrm{p}}^{2}-4 V_{\mathrm{s}}^{2}\right)}{\left(V_{\mathrm{p}}^{2}-V_{\mathrm{s}}^{2}\right)},
\end{aligned}
$$

where $v_{\text {dyn }}$ is the dynamic Poisson coefficient, $E_{\text {dyn }}$ is the dynamic Young modulus, $\rho_{\text {bulk }}$ is the bulk density, and $V_{\mathrm{p}}$ and $V_{\mathrm{s}}$ are the compressional and shear wave velocity.

Measurements were averaged out of 16 single measurements with a frequency of 80 or $250 \mathrm{kHz}$, depending on the sample dimension and shape.

Unconfined compressive strength was tested in a $1000 \mathrm{kN}$ testing frame ("Form + Test Prüfsysteme") according to the ASTM International (2014). Tests were both force and displacement controlled. Strain and force rates were individually set to achieve a testing duration of approximately $10 \mathrm{~min}$. Vertical displacement is measured with an external displacement transducer. 
Table 3. Quantity of data entry lines categorized after the petrographic ID (rank 3; Bär et al., 2019).

\begin{tabular}{lllllll}
\hline Petrographic ID & 10105 & 10210 & 10322 & 10881 & 10907 & 69619 \\
\hline Petrographic term & Plutonic rock & Volcanic rock & Dyke rock & $\begin{array}{l}\text { Metamorphic rock } \\
\text { (after educt) }\end{array}$ & $\begin{array}{l}\text { Metamorphic rock } \\
\text { (after chemistry, } \\
\text { fabric, mineral } \\
\text { content) }\end{array}$ \\
\hline Data rows documented & 3652 & 38 & 170 & 60 & 1216 & 68 \\
\hline
\end{tabular}

Elastic properties (Young's modulus and Poisson's ratio) are also measured in a $1000 \mathrm{kN}$ test frame (Form + Test Prüfsysteme) according to the ASTM International (2002) and Mutschler (2004).

Triaxial shear strength is measured in a $1000 \mathrm{kN}$ test frame (Wille Geotechnik) on samples of $55 \mathrm{~mm}$ in diameter and $110 \mathrm{~mm}$ in length according to ASTM International (2004). Samples are mounted in a Hoek cell and sealed with a rubber jacket. Confining pressures of up to $30 \mathrm{MPa}$ are supplied and constantly controlled with an external pump. Hydraulic oil was chosen as confining fluid. Due to the rock strength, hard rocks were commonly measured with 5, 10 and $20 \mathrm{MPa}$ confining pressure to achieve sample failure by applying the $1000 \mathrm{kN}$ testing frame. The sample strain is constantly logged with an external displacement transducer, measuring the strain of the loading rod against the top plate of the testing frame. Stress and strain rates were set specifically for each sampling location to meet the given testing duration provided by the standard for each test. Cohesion and internal friction angle were determined applying the Mohr-Coulomb criterion.

Tensile (or indirect tensile) strength is determined on rock disks of 55 and $64 \mathrm{~mm}$ diameter at length ratios of approximately $0.5: 1$ (diameter to length according to ASTM International, 2016). Therefore, the test procedure follows the Brazilian test procedure, where rock disks are compressed diametrically. Strain rates were individually set to meet the required test duration stated in ASTM International (2016).

\section{Status of the database and quality}

To date, the database is comprised of data from either student theses, scientific reports or self-supervised measurements conducted at the Technical University of Darmstadt. In total, 5204 data rows (Table 3) are entered in the database, which are distributed over 224 locations including quarries, abandoned quarries, outcrops and wells.

As shown in Fig. 3 the chosen sample locations are spread across most German outcrops of the MGCR, although many of the sampling points are concentrated in the Odenwald Crystalline Complex. Data of the Kyffhäuser Crystalline Complex are not included in the database so far. Also, data from further wells from either the Bavarian or Rhineland-Palatinate geological services might complement the database in the future. As shown in Fig. 3, more data from the Ruhla Mountains and Spessart are desirable, while the Odenwald is densely sampled. Nonetheless, more complex units, such as the Flasergranitoid Zone in the northern Odenwald, should also be sampled more densely, and in the future, the scope should be extended to include bulk rock geochemical analysis.

Unlike databases that compile literature data of petrophysical properties (e.g. Bär et al., 2020), all data in the presented database were measured at the same institute. Therefore, the dataset is homogeneous and all data were measured under equivalent conditions and application of the same laboratory devices. Furthermore, all measurements were performed by qualified lab professionals. Quality control was therefore an ongoing process while supervising the analysers and reviewing the final raw and processed data, resulting in a homogeneous dataset. Quality control and reliability indices as, for example, presented in Bär et al. (2020) are not necessary in the presented dataset.

\section{Data evaluation}

Table 4 comprises minimum and maximum data of bulk density, grain density, porosity, thermal conductivity, thermal diffusivity as well as compressional and shear wave velocity of all samples reported in Weinert et al. (2020b). Besides the minimum and maximum values, an average value for each petrographic ID as well as the parent ID is calculated and reported with a referring standard deviation and the number of samples $(n)$. Figure 4 displays the sample data in crossscatter plots.

\section{Data availability}

The complete dataset of thermophysical and rock mechanical properties can be accessed at https://doi.org/10.25534/tudatalib-278 (Weinert et al., 2020b).

Sample availability. Most of the samples are available at the Technical University of Darmstadt and are stored for at least 10 years after finalization of a student's thesis or scientific report. Data that are labelled with "archive samples of the Institut 
Table 4. Petrophysical properties averaged over the measured samples for each petrographic ID given in the database of Weinert et al. (2020b).

\begin{tabular}{|c|c|c|c|c|c|}
\hline & Min & Max & Average & Standard deviation & $n$ \\
\hline \multicolumn{6}{|l|}{10105 - plutonic rock: total average } \\
\hline Bulk density $\left[\mathrm{g} \mathrm{cm}^{-3}\right]$ & 2.35 & 2.99 & 2.68 & 0.10 & 671 \\
\hline Grain density $\left[\mathrm{g} \mathrm{cm}^{-3}\right]$ & 2.35 & 3.08 & 2.74 & 0.10 & 866 \\
\hline Porosity $[\%]$ & -1.43 & 23.79 & 1.89 & 1.97 & 632 \\
\hline Thermal conductivity $\left[\mathrm{W} \mathrm{m}^{-1} \mathrm{~K}^{-1}\right.$ ] & 0.35 & 4.22 & 2.44 & 0.43 & 1066 \\
\hline Thermal diffusivity $\left[\times 10^{-6} \mathrm{~m}^{2} \mathrm{~s}^{-1}\right]$ & 0.53 & 2.63 & 1.22 & 0.26 & 1048 \\
\hline Compressional wave velocity $\left[\mathrm{m} \mathrm{s}^{-1}\right]$ & 1776 & 8167 & 4795 & 1116 & 631 \\
\hline Shear wave velocity $\left[\mathrm{m} \mathrm{s}^{-1}\right]$ & 1027 & 4811 & 2680 & 659 & 631 \\
\hline \multicolumn{6}{|l|}{10110 - granite } \\
\hline Bulk density $\left[\mathrm{g} \mathrm{cm}^{-3}\right]$ & 2.39 & 2.95 & 2.62 & 0.08 & 238 \\
\hline Grain density $\left[\mathrm{g} \mathrm{cm}^{-3}\right]$ & 2.57 & 3.00 & 2.67 & 0.07 & 274 \\
\hline Porosity $[\%]$ & -1.43 & 9.55 & 1.93 & 1.59 & 233 \\
\hline Thermal conductivity $\left[\mathrm{W} \mathrm{m}^{-1} \mathrm{~K}^{-1}\right.$ ] & 1.73 & 4.22 & 2.74 & 0.42 & 293 \\
\hline Thermal diffusivity $\left[\times 10^{-6} \mathrm{~m}^{2} \mathrm{~s}^{-1}\right]$ & 0.76 & 2.63 & 1.44 & 0.28 & 292 \\
\hline Compressional wave velocity $\left[\mathrm{m} \mathrm{s}^{-1}\right]$ & 1776 & 7208 & 4711 & 1116 & 225 \\
\hline Shear wave velocity $\left[\mathrm{m} \mathrm{s}^{-1}\right]$ & 1100 & 4038 & 2623 & 679 & 225 \\
\hline \multicolumn{6}{|l|}{10114 - granodiorite } \\
\hline Bulk density $\left[\mathrm{g} \mathrm{cm}^{-3}\right]$ & 2.42 & 2.87 & 2.69 & 0.07 & 296 \\
\hline Grain density $\left[\mathrm{g} \mathrm{cm}^{-3}\right]$ & 2.35 & 2.87 & 2.73 & 0.07 & 378 \\
\hline Porosity $[\%]$ & 0.01 & 12.27 & 1.82 & 1.88 & 262 \\
\hline Thermal conductivity $\left[\mathrm{W} \mathrm{m}{ }^{-1} \mathrm{~K}^{-1}\right.$ ] & 0.35 & 3.39 & 2.48 & 0.36 & 394 \\
\hline Thermal diffusivity $\left[\times 10^{-6} \mathrm{~m}^{2} \mathrm{~s}^{-1}\right]$ & 0.72 & 2.08 & 1.22 & 0.19 & 386 \\
\hline Compressional wave velocity $\left[\mathrm{m} \mathrm{s}^{-1}\right]$ & 1802 & 7046 & 4489 & 975 & 284 \\
\hline Shear wave velocity $\left[\mathrm{m} \mathrm{s}^{-1}\right]$ & 1027 & 3984 & 2541 & 561 & 284 \\
\hline \multicolumn{6}{|l|}{10115 - tonalite } \\
\hline Bulk density $\left[\mathrm{g} \mathrm{cm}^{-3}\right]$ & - & - & - & - & - \\
\hline Grain density $\left[\mathrm{g} \mathrm{cm}^{-3}\right]$ & - & - & - & - & - \\
\hline Porosity $[\%]$ & - & - & - & - & - \\
\hline Thermal conductivity $\left[\mathrm{W} \mathrm{m}^{-1} \mathrm{~K}^{-1}\right.$ ] & 2.60 & 2.66 & 2.63 & 0.04 & 2 \\
\hline Thermal diffusivity $\left[\times 10^{-6} \mathrm{~m}^{2} \mathrm{~s}^{-1}\right]$ & 1.15 & 1.15 & 1.15 & 0.00 & 2 \\
\hline Compressional wave velocity $\left[\mathrm{m} \mathrm{s}^{-1}\right]$ & - & - & - & - & - \\
\hline Shear wave velocity $\left[\mathrm{m} \mathrm{s}^{-1}\right]$ & - & - & - & - & - \\
\hline \multicolumn{6}{|l|}{10122 - quartz diorite } \\
\hline Bulk density $\left[\mathrm{g} \mathrm{cm}^{-3}\right]$ & 2.58 & 2.78 & 2.73 & 0.04 & 27 \\
\hline Grain density $\left[\mathrm{g} \mathrm{cm}^{-3}\right]$ & 2.78 & 2.99 & 2.81 & 0.04 & 38 \\
\hline Porosity $[\%]$ & 0.65 & 8 & 2.27 & 1.47 & 27 \\
\hline Thermal conductivity $\left[\mathrm{W} \mathrm{m}^{-1} \mathrm{~K}^{-1}\right.$ ] & 1.93 & 2.57 & 2.22 & 0.16 & 38 \\
\hline Thermal diffusivity $\left[\times 10^{-6} \mathrm{~m}^{2} \mathrm{~s}^{-1}\right]$ & 0.91 & 1.39 & 1.07 & 0.10 & 38 \\
\hline Compressional wave velocity $\left[\mathrm{m} \mathrm{s}^{-1}\right]$ & 4172 & 6780 & 5674 & 642 & 38 \\
\hline Shear wave velocity $\left[\mathrm{m} \mathrm{s}^{-1}\right]$ & 1883 & 3979 & 3080 & 458 & 38 \\
\hline
\end{tabular}


Table 4. Continued.

\begin{tabular}{|c|c|c|c|c|c|}
\hline & Min & Max & Average & Standard deviation & $n$ \\
\hline \multicolumn{6}{|l|}{10123 - quartz gabbro } \\
\hline Bulk density $\left[\mathrm{g} \mathrm{cm}^{-3}\right]$ & - & - & - & - & - \\
\hline Grain density $\left[\mathrm{g} \mathrm{cm}^{-3}\right]$ & 2.84 & 2.84 & 2.84 & - & 1 \\
\hline Porosity $[\%]$ & - & - & - & - & - \\
\hline Thermal conductivity $\left[\mathrm{W} \mathrm{m}{ }^{-1} \mathrm{~K}^{-1}\right.$ ] & 2.35 & 2.35 & 2.35 & - & 1 \\
\hline Thermal diffusivity $\left[\times 10^{-6} \mathrm{~m}^{2} \mathrm{~s}^{-1}\right]$ & 1.25 & 1.25 & 1.25 & - & 1 \\
\hline Compressional wave velocity $\left[\mathrm{m} \mathrm{s}^{-1}\right]$ & 5000 & 5000 & 5000 & - & 1 \\
\hline Shear wave velocity $\left[\mathrm{m} \mathrm{s}^{-1}\right]$ & 2609 & 2609 & 2609 & - & 1 \\
\hline \multicolumn{6}{|l|}{10131 - diorite } \\
\hline Bulk density $\left[\mathrm{g} \mathrm{cm}^{-3}\right]$ & 2.35 & 2.89 & 2.72 & 0.10 & 60 \\
\hline Grain density $\left[\mathrm{g} \mathrm{cm}^{-3}\right]$ & 2.65 & 3.08 & 2.82 & 0.07 & 111 \\
\hline Porosity $[\%]$ & -0.41 & 23.79 & 2.59 & 3.51 & 60 \\
\hline Thermal conductivity $\left[\mathrm{W} \mathrm{m}{ }^{-1} \mathrm{~K}^{-1}\right.$ ] & 0.95 & 3.81 & 2.13 & 0.37 & 241 \\
\hline Thermal diffusivity $\left[\times 10^{-6} \mathrm{~m}^{2} \mathrm{~s}^{-1}\right]$ & 0.53 & 1.73 & 1.05 & 0.17 & 243 \\
\hline Compressional wave velocity $\left[\mathrm{m} \mathrm{s}^{-1}\right]$ & 4636 & 8167 & 6122 & 737 & 51 \\
\hline Shear wave velocity $\left[\mathrm{m} \mathrm{s}^{-1}\right]$ & 2532 & 4811 & 3405 & 627 & 51 \\
\hline \multicolumn{6}{|l|}{10132 - gabbro } \\
\hline Bulk density $\left[\mathrm{g} \mathrm{cm}^{-3}\right]$ & 2.61 & 2.99 & 2.89 & 0.09 & 37 \\
\hline Grain density $\left[\mathrm{g} \mathrm{cm}^{-3}\right]$ & 2.62 & 2.99 & 2.90 & 0.08 & 51 \\
\hline Porosity $[\%]$ & -0.46 & 4.55 & 0.62 & 0.92 & 37 \\
\hline Thermal conductivity $\left[\mathrm{W} \mathrm{m}{ }^{-1} \mathrm{~K}^{-1}\right.$ ] & 1.54 & 3.07 & 2.18 & 0.23 & 95 \\
\hline Thermal diffusivity $\left[\times 10^{-6} \mathrm{~m}^{2} \mathrm{~s}^{-1}\right]$ & 0.84 & 1.54 & 1.04 & 0.11 & 84 \\
\hline Compressional wave velocity $\left[\mathrm{m} \mathrm{s}^{-1}\right]$ & 2644 & 7052 & 5025 & 1283 & 27 \\
\hline Shear wave velocity $\left[\mathrm{m} \mathrm{s}^{-1}\right]$ & 1602 & 3886 & 2820 & 677 & 27 \\
\hline \multicolumn{6}{|l|}{10355 - micro-diorite } \\
\hline Bulk density $\left[\mathrm{g} \mathrm{cm}^{-3}\right]$ & 2.76 & 2.86 & 2.81 & 0.04 & 13 \\
\hline Grain density $\left[\mathrm{g} \mathrm{cm}^{-3}\right]$ & 2.83 & 2.89 & 2.86 & 0.01 & 13 \\
\hline Porosity $[\%]$ & 0.55 & 3.30 & 1.92 & 1.12 & 13 \\
\hline Thermal conductivity $\left[\mathrm{W} \mathrm{m}{ }^{-1} \mathrm{~K}^{-1}\right.$ ] & 2.38 & 2.44 & 2.41 & 0.04 & 2 \\
\hline Thermal diffusivity $\left[\times 10^{-6} \mathrm{~m}^{2} \mathrm{~s}^{-1}\right]$ & 1.35 & 1.39 & 1.37 & 0.03 & 2 \\
\hline Compressional wave velocity $\left[\mathrm{m} \mathrm{s}^{-1}\right]$ & 3566 & 5096 & 4409 & 751 & 5 \\
\hline Shear wave velocity $\left[\mathrm{m} \mathrm{s}^{-1}\right]$ & 1888 & 2157 & 1998 & 112 & 5 \\
\hline \multicolumn{6}{|l|}{10210 - volcanic rock: total average } \\
\hline Bulk density $\left[\mathrm{g} \mathrm{cm}^{-3}\right]$ & 2.36 & 3.01 & 2.68 & 0.24 & 8 \\
\hline Grain density $\left[\mathrm{g} \mathrm{cm}^{-3}\right]$ & 2.65 & 2.96 & 2.77 & 0.10 & 10 \\
\hline Porosity $[\%]$ & -0.65 & 13.02 & 5.27 & 5.05 & 8 \\
\hline Thermal conductivity $\left[\mathrm{W} \mathrm{m}^{-1} \mathrm{~K}^{-1}\right.$ ] & 1.29 & 3.56 & 2.21 & 0.78 & 23 \\
\hline Thermal diffusivity $\left[\times 10^{-6} \mathrm{~m}^{2} \mathrm{~s}^{-1}\right]$ & 0.68 & 2.32 & 1.21 & 0.47 & 23 \\
\hline Compressional wave velocity $\left[\mathrm{m} \mathrm{s}^{-1}\right]$ & 5845 & 6161 & 6003 & 224 & 2 \\
\hline Shear wave velocity $\left[\mathrm{m} \mathrm{s}^{-1}\right]$ & 3219 & 3552 & 3386 & 236 & 2 \\
\hline \multicolumn{6}{|l|}{10224 - trachyte } \\
\hline Bulk density $\left[\mathrm{g} \mathrm{cm}^{-3}\right]$ & - & - & - & - & - \\
\hline Grain density $\left[\mathrm{g} \mathrm{cm}^{-3}\right]$ & - & - & - & - & - \\
\hline Porosity $[\%]$ & - & - & - & - & - \\
\hline Thermal conductivity $\left[\mathrm{W} \mathrm{m}^{-1} \mathrm{~K}^{-1}\right.$ ] & 1.80 & 1.89 & 1.85 & 0.05 & 3 \\
\hline Thermal diffusivity $\left[\times 10^{-6} \mathrm{~m}^{2} \mathrm{~s}^{-1}\right]$ & 1.05 & 1.08 & 1.07 & 0.02 & 4 \\
\hline Compressional wave velocity $\left[\mathrm{m} \mathrm{s}^{-1}\right]$ & - & - & - & - & - \\
\hline Shear wave velocity $\left[\mathrm{m} \mathrm{s}^{-1}\right]$ & - & - & - & - & - \\
\hline
\end{tabular}


Table 4. Continued.

\begin{tabular}{|c|c|c|c|c|c|}
\hline & Min & Max & Average & Standard deviation & $n$ \\
\hline \multicolumn{6}{|l|}{10231 - basalt } \\
\hline Bulk density $\left[\mathrm{g} \mathrm{cm}^{-3}\right]$ & 2.36 & 3.01 & 2.68 & 0.24 & 8 \\
\hline Grain density $\left[\mathrm{g} \mathrm{cm}^{-3}\right]$ & 2.65 & 2.96 & 2.77 & 0.10 & 10 \\
\hline Porosity $[\%]$ & -0.65 & 13.02 & 5.27 & 5.05 & 7 \\
\hline Thermal conductivity $\left[\mathrm{W} \mathrm{m}{ }^{-1} \mathrm{~K}^{-1}\right]$ & 1.30 & 3.45 & 2.07 & 0.78 & 10 \\
\hline Thermal diffusivity $\left[\times 10^{-6} \mathrm{~m}^{2} \mathrm{~s}^{-1}\right]$ & 0.71 & 2.18 & 1.11 & 0.46 & 10 \\
\hline Compressional wave velocity $\left[\mathrm{m} \mathrm{s}^{-1}\right]$ & 5845 & 6161 & 6003 & 224 & 2 \\
\hline Shear wave velocity $\left[\mathrm{m} \mathrm{s}^{-1}\right]$ & 3219 & 3552 & 3386 & 236 & 2 \\
\hline \multicolumn{6}{|l|}{10322 - dyke rock: total average } \\
\hline Bulk density $\left[\mathrm{g} \mathrm{cm}^{-3}\right]$ & 2.65 & 2.78 & 2.65 & 0.07 & 14 \\
\hline Grain density $\left[\mathrm{g} \mathrm{cm}^{-3}\right]$ & 2.61 & 2.96 & 2.83 & 0.12 & 26 \\
\hline Porosity $[\%]$ & 0.20 & 14.55 & 9.56 & 3.33 & 14 \\
\hline Thermal conductivity $\left[\mathrm{W} \mathrm{m}^{-1} \mathrm{~K}^{-1}\right.$ ] & 1.57 & 3.28 & 2.12 & 0.31 & 47 \\
\hline Thermal diffusivity $\left[\times 10^{-6} \mathrm{~m}^{2} \mathrm{~s}^{-1}\right]$ & 0.79 & 1.67 & 1.07 & 0.15 & 49 \\
\hline Compressional wave velocity $\left[\mathrm{m} \mathrm{s}^{-1}\right]$ & 1120 & 6706 & 3814 & 1518 & 25 \\
\hline Shear wave velocity $\left[\mathrm{m} \mathrm{s}^{-1}\right]$ & 673 & 3341 & 2035 & 863 & 25 \\
\hline \multicolumn{6}{|l|}{10325 - aplite } \\
\hline Bulk density $\left[\mathrm{g} \mathrm{cm}^{-3}\right]$ & 2.78 & 2.78 & 2.78 & - & 1 \\
\hline Grain density $\left[\mathrm{g} \mathrm{cm}^{-3}\right]$ & 2.61 & 2.61 & 2.61 & - & 1 \\
\hline Porosity $[\%]$ & 0.20 & 0.20 & 0.20 & - & 1 \\
\hline Thermal conductivity $\left[\mathrm{W} \mathrm{m}{ }^{-1} \mathrm{~K}^{-1}\right.$ ] & 2.10 & 3.28 & 2.35 & 0.42 & 7 \\
\hline Thermal diffusivity $\left[\times 10^{-6} \mathrm{~m}^{2} \mathrm{~s}^{-1}\right]$ & 1.09 & 1.67 & 1.24 & 0.21 & 7 \\
\hline Compressional wave velocity $\left[\mathrm{m} \mathrm{s}^{-1}\right]$ & - & - & - & - & - \\
\hline Shear wave velocity $\left[\mathrm{m} \mathrm{s}^{-1}\right]$ & - & - & - & - & - \\
\hline \multicolumn{6}{|l|}{10329 - granitic subvolcanic rock } \\
\hline Bulk density $\left[\mathrm{g} \mathrm{cm}^{-3}\right]$ & - & - & - & - & - \\
\hline Grain density $\left[\mathrm{g} \mathrm{cm}^{-3}\right]$ & 2.63 & 2.63 & 2.63 & 0.00 & 2 \\
\hline Porosity $[\%]$ & - & - & - & - & - \\
\hline Thermal conductivity $\left[\mathrm{W} \mathrm{m}{ }^{-1} \mathrm{~K}^{-1}\right.$ ] & 2.56 & 2.61 & 2.58 & 0.03 & 2 \\
\hline Thermal diffusivity $\left[\times 10^{-6} \mathrm{~m}^{2} \mathrm{~s}^{-1}\right]$ & 1.32 & 1.34 & 1.33 & 0.01 & 2 \\
\hline Compressional wave velocity $\left[\mathrm{m} \mathrm{s}^{-1}\right]$ & 3436 & 3757 & 3596 & 227 & 2 \\
\hline Shear wave velocity $\left[\mathrm{m} \mathrm{s}^{-1}\right]$ & 2012 & 2069 & 2041 & 40 & 2 \\
\hline \multicolumn{6}{|l|}{10336 - porphyritic granite } \\
\hline Bulk density $\left[\mathrm{g} \mathrm{cm}^{-3}\right]$ & 2.53 & 2.74 & 2.64 & 0.05 & 13 \\
\hline Grain density $\left[\mathrm{g} \mathrm{cm}^{-3}\right]$ & 2.90 & 2.96 & 2.94 & 0.02 & 13 \\
\hline Porosity $[\%]$ & 6.71 & 14.55 & 10.28 & 2.04 & 13 \\
\hline Thermal conductivity $\left[\mathrm{W} \mathrm{m}^{-1} \mathrm{~K}^{-1}\right.$ ] & 1.57 & 1.98 & 1.81 & 0.11 & 13 \\
\hline Thermal diffusivity $\left[\times 10^{-6} \mathrm{~m}^{2} \mathrm{~s}^{-1}\right]$ & 0.82 & 1.05 & 0.94 & 0.07 & 13 \\
\hline Compressional wave velocity $\left[\mathrm{m} \mathrm{s}^{-1}\right]$ & 1120 & 3271 & 1600 & 656 & 13 \\
\hline Shear wave velocity $\left[\mathrm{m} \mathrm{s}^{-1}\right]$ & 673 & 1874 & 1300 & 298 & 13 \\
\hline \multicolumn{6}{|l|}{10337 - porphyritic granodiorite } \\
\hline Bulk density $\left[\mathrm{g} \mathrm{cm}^{-3}\right]$ & - & - & - & - & - \\
\hline Grain density $\left[\mathrm{g} \mathrm{cm}^{-3}\right]$ & 2.68 & 2.70 & 2.69 & 0.01 & 4 \\
\hline Porosity $[\%]$ & - & - & - & - & - \\
\hline Thermal conductivity $\left[\mathrm{W} \mathrm{m}^{-1} \mathrm{~K}^{-1}\right.$ ] & 2.38 & 2.48 & 2.44 & 0.04 & 4 \\
\hline Thermal diffusivity $\left[\times 10^{-6} \mathrm{~m}^{2} \mathrm{~s}^{-1}\right]$ & 1.12 & 1.24 & 1.18 & 0.05 & 4 \\
\hline Compressional wave velocity $\left[\mathrm{m} \mathrm{s}^{-1}\right]$ & 4993 & 5809 & 5399 & 466 & 4 \\
\hline Shear wave velocity $\left[\mathrm{m} \mathrm{s}^{-1}\right]$ & 3021 & 3341 & 3192 & 150 & 4 \\
\hline
\end{tabular}


Table 4. Continued.

\begin{tabular}{|c|c|c|c|c|c|}
\hline & Min & $\operatorname{Max}$ & Average & Standard deviation & $n$ \\
\hline \multicolumn{6}{|l|}{10360 - porphyritic diorite } \\
\hline Bulk density $\left[\mathrm{g} \mathrm{cm}^{-3}\right]$ & - & - & - & - & - \\
\hline Grain density $\left[\mathrm{g} \mathrm{cm}^{-3}\right]$ & 2.74 & 2.78 & 2.76 & 0.02 & 3 \\
\hline Porosity $[\%]$ & - & - & - & - & - \\
\hline Thermal conductivity $\left[\mathrm{W} \mathrm{m}{ }^{-1} \mathrm{~K}^{-1}\right]$ & 2.05 & 2.56 & 2.18 & 0.17 & 9 \\
\hline Thermal diffusivity $\left[\times 10^{-6} \mathrm{~m}^{2} \mathrm{~s}^{-1}\right]$ & 0.92 & 1.19 & 1.04 & 0.11 & 9 \\
\hline Compressional wave velocity $\left[\mathrm{m} \mathrm{s}^{-1}\right]$ & 4297 & 5622 & 4857 & 686 & 3 \\
\hline Shear wave velocity $\left[\mathrm{m} \mathrm{s}^{-1}\right]$ & 2624 & 3310 & 2893 & 366 & 3 \\
\hline \multicolumn{6}{|l|}{58823 - diabase } \\
\hline Bulk density $\left[\mathrm{g} \mathrm{cm}^{-3}\right]$ & - & - & - & - & - \\
\hline Grain density $\left[\mathrm{g} \mathrm{cm}^{-3}\right]$ & - & - & - & - & - \\
\hline Porosity $[\%]$ & - & - & - & - & - \\
\hline Thermal conductivity $\left[\mathrm{W} \mathrm{m}^{-1} \mathrm{~K}^{-1}\right.$ ] & 1.70 & 2.04 & 1.88 & 0.14 & 4 \\
\hline Thermal diffusivity $\left[\times 10^{-6} \mathrm{~m}^{2} \mathrm{~s}^{-1}\right]$ & 0.79 & 1.09 & 1.02 & 0.12 & 6 \\
\hline Compressional wave velocity $\left[\mathrm{m} \mathrm{s}^{-1}\right]$ & - & - & - & - & - \\
\hline Shear wave velocity $\left[\mathrm{m} \mathrm{s}^{-1}\right]$ & - & - & - & - & - \\
\hline \multicolumn{6}{|l|}{58827 - dioritic lamprophyre } \\
\hline Bulk density $\left[\mathrm{g} \mathrm{cm}^{-3}\right]$ & - & - & - & - & - \\
\hline Grain density $\left[\mathrm{g} \mathrm{cm}^{-3}\right]$ & - & - & - & - & - \\
\hline Porosity $[\%]$ & - & - & - & - & - \\
\hline Thermal conductivity $\left[\mathrm{W} \mathrm{m}{ }^{-1} \mathrm{~K}^{-1}\right.$ ] & 2.49 & 2.49 & 2.49 & - & 1 \\
\hline Thermal diffusivity $\left[\times 10^{-6} \mathrm{~m}^{2} \mathrm{~s}^{-1}\right]$ & 1.12 & 1.12 & 1.12 & & 1 \\
\hline Compressional wave velocity $\left[\mathrm{m} \mathrm{s}^{-1}\right]$ & - & - & - & - & - \\
\hline Shear wave velocity $\left[\mathrm{m} \mathrm{s}^{-1}\right]$ & - & - & - & - & - \\
\hline \multicolumn{6}{|l|}{58830 - kersantite } \\
\hline Bulk density $\left[\mathrm{g} \mathrm{cm}^{-3}\right]$ & - & - & - & - & - \\
\hline Grain density $\left[\mathrm{g} \mathrm{cm}^{-3}\right]$ & 2.82 & 2.83 & 2.83 & 0.01 & 3 \\
\hline Porosity $[\%]$ & - & - & - & - & - \\
\hline Thermal conductivity $\left[\mathrm{W} \mathrm{m}{ }^{-1} \mathrm{~K}^{-1}\right.$ ] & 2.01 & 2.36 & 2.17 & 0.15 & 7 \\
\hline Thermal diffusivity $\left[\times 10^{-6} \mathrm{~m}^{2} \mathrm{~s}^{-1}\right]$ & 0.95 & 1.11 & 1.05 & 0.07 & 7 \\
\hline Compressional wave velocity $\left[\mathrm{m} \mathrm{s}^{-1}\right]$ & 5431 & 6707 & 6061 & 638 & 3 \\
\hline Shear wave velocity $\left[\mathrm{m} \mathrm{s}^{-1}\right]$ & 2634 & 3017 & 2815 & 192 & 3 \\
\hline \multicolumn{6}{|l|}{10907 - metamorphic rock (total) } \\
\hline Bulk density $\left[\mathrm{g} \mathrm{cm}^{-3}\right]$ & 2.33 & 3.05 & 2.68 & 0.12 & 281 \\
\hline Grain density $\left[\mathrm{g} \mathrm{cm}^{-3}\right]$ & 2.50 & 3.12 & 2.71 & 0.12 & 336 \\
\hline Porosity $[\%]$ & -0.57 & 10.35 & 1.36 & 1.56 & 265 \\
\hline Thermal conductivity $\left[\mathrm{W} \mathrm{m}{ }^{-1} \mathrm{~K}^{-1}\right.$ ] & 1.24 & 6.00 & 2.61 & 0.54 & 988 \\
\hline Thermal diffusivity $\left[\times 10^{-6} \mathrm{~m}^{2} \mathrm{~s}^{-1}\right]$ & 0.52 & 5.80 & 1.35 & 0.39 & 902 \\
\hline Compressional wave velocity $\left[\mathrm{m} \mathrm{s}^{-1}\right.$ ] & 1553 & 7456 & 4589 & 1069 & 256 \\
\hline Shear wave velocity $\left[\mathrm{m} \mathrm{s}^{-1}\right]$ & 1103 & 3890 & 2550 & 584 & 256 \\
\hline \multicolumn{6}{|l|}{10895 - meta granite } \\
\hline Bulk density $\left[\mathrm{g} \mathrm{cm}^{-3}\right]$ & - & - & - & - & - \\
\hline Grain density $\left[\mathrm{g} \mathrm{cm}^{-3}\right]$ & 2.62 & 2.70 & 2.67 & 0.03 & 9 \\
\hline Porosity $[\%]$ & - & - & - & - & - \\
\hline Thermal conductivity $\left[\mathrm{W} \mathrm{m}{ }^{-1} \mathrm{~K}^{-1}\right.$ ] & 2.44 & 3.22 & 2.81 & 0.19 & 43 \\
\hline Thermal diffusivity $\left[\times 10^{-6} \mathrm{~m}^{2} \mathrm{~s}^{-1}\right]$ & 1.11 & 1.95 & 1.51 & 0.23 & 43 \\
\hline Compressional wave velocity $\left[\mathrm{m} \mathrm{s}^{-1}\right]$ & 1093 & 6570 & 4765 & 825 & 25 \\
\hline Shear wave velocity $\left[\mathrm{m} \mathrm{s}^{-1}\right]$ & 1912 & 3436 & 2809 & 403 & 25 \\
\hline
\end{tabular}


Table 4. Continued.

\begin{tabular}{|c|c|c|c|c|c|}
\hline & Min & Max & Average & Standard deviation & $n$ \\
\hline \multicolumn{6}{|l|}{10898 - meta gabbro } \\
\hline Bulk density $\left[\mathrm{g} \mathrm{cm}^{-3}\right]$ & - & - & - & - & - \\
\hline Grain density $\left[\mathrm{g} \mathrm{cm}^{-3}\right]$ & - & - & 2.88 & - & 1 \\
\hline Porosity $[\%]$ & - & - & - & - & - \\
\hline Thermal conductivity $\left[\mathrm{W} \mathrm{m}^{-1} \mathrm{~K}^{-1}\right.$ ] & 2.39 & 2.67 & 2.51 & 0.14 & 3 \\
\hline Thermal diffusivity $\left[\times 10^{-6} \mathrm{~m}^{2} \mathrm{~s}^{-1}\right]$ & 0.95 & 1.11 & 1.05 & 0.09 & 3 \\
\hline Compressional wave velocity $\left[\mathrm{m} \mathrm{s}^{-1}\right]$ & 5202 & 5789 & 5496 & 415 & 2 \\
\hline Shear wave velocity $\left[\mathrm{m} \mathrm{s}^{-1}\right]$ & 3111 & 3262 & 3186 & 106 & 2 \\
\hline \multicolumn{6}{|l|}{10917 - quartzite } \\
\hline Bulk density $\left[\mathrm{g} \mathrm{cm}^{-3}\right]$ & 2.62 & 2.62 & 2.62 & 0.00 & 2 \\
\hline Grain density $\left[\mathrm{g} \mathrm{cm}^{-3}\right]$ & 2.65 & 2.65 & 2.65 & 0.00 & 2 \\
\hline Porosity $[\%]$ & 1.16 & 1.16 & 1.16 & 0.00 & 2 \\
\hline Thermal conductivity $\left[\mathrm{W} \mathrm{m}{ }^{-1} \mathrm{~K}^{-1}\right.$ ] & 5.24 & 6.11 & 5.73 & 0.44 & 3 \\
\hline Thermal diffusivity $\left[\times 10^{-6} \mathrm{~m}^{2} \mathrm{~s}^{-1}\right]$ & 3.67 & 4.18 & 3.96 & 0.26 & 3 \\
\hline Compressional wave velocity $\left[\mathrm{m} \mathrm{s}^{-1}\right]$ & - & - & - & - & - \\
\hline Shear wave velocity $\left[\mathrm{m} \mathrm{s}^{-1}\right]$ & - & - & - & - & - \\
\hline \multicolumn{6}{|l|}{10926 - phyllite } \\
\hline Bulk density $\left[\mathrm{g} \mathrm{cm}^{-3}\right]$ & - & - & - & - & - \\
\hline Grain density $\left[\mathrm{g} \mathrm{cm}^{-3}\right]$ & - & - & - & - & - \\
\hline Porosity $[\%]$ & - & - & - & - & - \\
\hline Thermal conductivity $\left[\mathrm{W} \mathrm{m}^{-1} \mathrm{~K}^{-1}\right.$ ] & 2.45 & 4.14 & 3.37 & 0.45 & 11 \\
\hline Thermal diffusivity $\left[\times 10^{-6} \mathrm{~m}^{2} \mathrm{~s}^{-1}\right]$ & - & - & - & - & - \\
\hline Compressional wave velocity $\left[\mathrm{m} \mathrm{s}^{-1}\right]$ & - & - & - & - & - \\
\hline Shear wave velocity $\left[\mathrm{m} \mathrm{s}^{-1}\right]$ & - & - & - & - & - \\
\hline \multicolumn{6}{|l|}{10945 - gneiss } \\
\hline Bulk density $\left[\mathrm{g} \mathrm{cm}^{-3}\right]$ & 2.33 & 2.82 & 2.62 & 0.05 & 186 \\
\hline Grain density $\left[\mathrm{g} \mathrm{cm}^{-3}\right]$ & 2.55 & 2.88 & 2.65 & 0.04 & 199 \\
\hline Porosity $[\%]$ & 0.01 & 10.35 & 1.14 & 1.27 & 178 \\
\hline Thermal conductivity $\left[\mathrm{W} \mathrm{m}{ }^{-1} \mathrm{~K}^{-1}\right.$ ] & 1.60 & 3.53 & 2.79 & 0.32 & 198 \\
\hline Thermal diffusivity $\left[\times 10^{-6} \mathrm{~m}^{2} \mathrm{~s}^{-1}\right]$ & 0.60 & 1.98 & 1.36 & 0.20 & 194 \\
\hline Compressional wave velocity $\left[\mathrm{m} \mathrm{s}^{-1}\right]$ & 1886 & 6150 & 4291 & 1062 & 131 \\
\hline Shear wave velocity $\left[\mathrm{m} \mathrm{s}^{-1}\right]$ & 1103 & 3489 & 2334 & 551 & 131 \\
\hline \multicolumn{6}{|l|}{10949 - biotite gneiss } \\
\hline Bulk density $\left[\mathrm{g} \mathrm{cm}^{-3}\right]$ & 2.62 & 2.75 & 2.65 & 0.04 & 11 \\
\hline Grain density $\left[\mathrm{g} \mathrm{cm}^{-3}\right]$ & 2.51 & 2.77 & 2.63 & 0.08 & 13 \\
\hline Porosity $[\%]$ & 0.06 & 4.46 & 1.62 & 1.58 & 9 \\
\hline Thermal conductivity $\left[\mathrm{W} \mathrm{m}^{-1} \mathrm{~K}^{-1}\right.$ ] & 1.96 & 2.98 & 2.46 & 0.27 & 34 \\
\hline Thermal diffusivity $\left[\times 10^{-6} \mathrm{~m}^{2} \mathrm{~s}^{-1}\right]$ & 0.88 & 1.67 & 1.39 & 0.19 & 30 \\
\hline Compressional wave velocity $\left[\mathrm{m} \mathrm{s}^{-1}\right]$ & - & - & - & - & - \\
\hline Shear wave velocity $\left[\mathrm{m} \mathrm{s}^{-1}\right]$ & - & - & - & - & - \\
\hline \multicolumn{6}{|l|}{10961 - garnet biotite gneiss } \\
\hline Bulk density $\left[\mathrm{g} \mathrm{cm}^{-3}\right]$ & 2.73 & 2.74 & 2.74 & 0.00 & 3 \\
\hline Grain density $\left[\mathrm{g} \mathrm{cm}^{-3}\right]$ & 2.74 & 2.76 & 2.75 & 0.01 & 5 \\
\hline Porosity $[\%]$ & 0.15 & 0.50 & 0.33 & 0.25 & 2 \\
\hline Thermal conductivity $\left[\mathrm{W} \mathrm{m}^{-1} \mathrm{~K}^{-1}\right.$ ] & 2.57 & 4.15 & 3.63 & 0.43 & 18 \\
\hline Thermal diffusivity $\left[\times 10^{-6} \mathrm{~m}^{2} \mathrm{~s}^{-1}\right]$ & 0.71 & 1.94 & 1.64 & 0.29 & 18 \\
\hline Compressional wave velocity $\left[\mathrm{m} \mathrm{s}^{-1}\right]$ & - & - & - & - & - \\
\hline Shear wave velocity $\left[\mathrm{m} \mathrm{s}^{-1}\right]$ & - & - & - & - & - \\
\hline
\end{tabular}


Table 4. Continued.

\begin{tabular}{|c|c|c|c|c|c|}
\hline & Min & Max & Average & Standard deviation & $n$ \\
\hline \multicolumn{6}{|l|}{10966 - garnet plagioclase gneiss } \\
\hline Bulk density $\left[\mathrm{g} \mathrm{cm}^{-3}\right]$ & - & - & - & - & - \\
\hline Grain density $\left[\mathrm{g} \mathrm{cm}^{-3}\right]$ & - & - & - & - & - \\
\hline Porosity $[\%]$ & - & - & - & - & - \\
\hline Thermal conductivity $\left[\mathrm{W} \mathrm{m}{ }^{-1} \mathrm{~K}^{-1}\right]$ & 4.21 & 4.21 & 4.21 & - & 1 \\
\hline Thermal diffusivity $\left[\times 10^{-6} \mathrm{~m}^{2} \mathrm{~s}^{-1}\right]$ & 2.34 & 2.34 & 2.34 & - & 1 \\
\hline Compressional wave velocity $\left[\mathrm{m} \mathrm{s}^{-1}\right]$ & - & - & - & - & - \\
\hline Shear wave velocity $\left[\mathrm{m} \mathrm{s}^{-1}\right]$ & - & - & - & - & - \\
\hline \multicolumn{6}{|l|}{10968 - hornblende biotite gneiss } \\
\hline Bulk density $\left[\mathrm{g} \mathrm{cm}^{-3}\right]$ & 2.63 & 2.95 & 2.76 & 0.06 & 15 \\
\hline Grain density $\left[\mathrm{g} \mathrm{cm}^{-3}\right]$ & 2.69 & 2.94 & 2.77 & 0.05 & 29 \\
\hline Porosity $[\%]$ & 0.00 & 2.18 & 0.45 & 0.58 & 12 \\
\hline Thermal conductivity $\left[\mathrm{W} \mathrm{m}{ }^{-1} \mathrm{~K}^{-1}\right.$ ] & 1.75 & 4.46 & 2.55 & 0.62 & 30 \\
\hline Thermal diffusivity $\left[\times 10^{-6} \mathrm{~m}^{2} \mathrm{~s}^{-1}\right]$ & 0.94 & 2.76 & 1.35 & 0.48 & 25 \\
\hline Compressional wave velocity $\left[\mathrm{m} \mathrm{s}^{-1}\right]$ & - & - & - & - & - \\
\hline Shear wave velocity $\left[\mathrm{m} \mathrm{s}^{-1}\right]$ & - & - & - & - & - \\
\hline \multicolumn{6}{|l|}{10970 - muscovite biotite gneiss } \\
\hline Bulk density $\left[\mathrm{g} \mathrm{cm}^{-3}\right]$ & 2.61 & 2.64 & 2.63 & 0.01 & 6 \\
\hline Grain density $\left[\mathrm{g} \mathrm{cm}^{-3}\right]$ & 2.50 & 2.61 & 2.57 & 0.05 & 6 \\
\hline Porosity $[\%]$ & 0.33 & 5.35 & 2.70 & 2.11 & 5 \\
\hline Thermal conductivity $\left[\mathrm{W} \mathrm{m}{ }^{-1} \mathrm{~K}^{-1}\right.$ ] & 1.92 & 2.62 & 2.36 & 0.23 & 18 \\
\hline Thermal diffusivity $\left[\times 10^{-6} \mathrm{~m}^{2} \mathrm{~s}^{-1}\right]$ & 0.94 & 1.89 & 1.53 & 0.27 & 18 \\
\hline Compressional wave velocity $\left[\mathrm{m} \mathrm{s}^{-1}\right]$ & - & - & - & - & - \\
\hline Shear wave velocity $\left[\mathrm{m} \mathrm{s}^{-1}\right]$ & - & - & - & - & - \\
\hline \multicolumn{6}{|l|}{10989 - amphibolite } \\
\hline Bulk density $\left[\mathrm{g} \mathrm{cm}^{-3}\right]$ & 2.33 & 3.05 & 2.85 & 0.14 & 56 \\
\hline Grain density $\left[\mathrm{g} \mathrm{cm}^{-3}\right]$ & 2.60 & 3.12 & 2.90 & 0.12 & 66 \\
\hline Porosity $[\%]$ & -0.57 & 10.35 & 2.16 & 2.14 & 55 \\
\hline Thermal conductivity $\left[\mathrm{W} \mathrm{m}{ }^{-1} \mathrm{~K}^{-1}\right.$ ] & 1.24 & 3.80 & 2.20 & 0.40 & 80 \\
\hline Thermal diffusivity $\left[\times 10^{-6} \mathrm{~m}^{2} \mathrm{~s}^{-1}\right]$ & 0.63 & 2.40 & 1.09 & 0.24 & 80 \\
\hline Compressional wave velocity $\left[\mathrm{m} \mathrm{s}^{-1}\right]$ & 1896 & 6305 & 4931 & 1000 & 19 \\
\hline Shear wave velocity $\left[\mathrm{m} \mathrm{s}^{-1}\right]$ & 1173 & 3520 & 2806 & 547 & 19 \\
\hline \multicolumn{6}{|l|}{10990 - biotite-bearing amphibolite } \\
\hline Bulk density $\left[\mathrm{g} \mathrm{cm}^{-3}\right]$ & 2.58 & 2.63 & 2.61 & 0.04 & 2 \\
\hline Grain density $\left[\mathrm{g} \mathrm{cm}^{-3}\right]$ & 2.64 & 2.66 & 2.65 & 0.02 & 2 \\
\hline Porosity $[\%]$ & 1.11 & 2.15 & 1.63 & 0.73 & 2 \\
\hline Thermal conductivity $\left[\mathrm{W} \mathrm{m}^{-1} \mathrm{~K}^{-1}\right.$ ] & 2.33 & 2.56 & 2.48 & 0.13 & 3 \\
\hline Thermal diffusivity $\left[\times 10^{-6} \mathrm{~m}^{2} \mathrm{~s}^{-1}\right]$ & 1.52 & 1.57 & 1.54 & 0.03 & 3 \\
\hline Compressional wave velocity $\left[\mathrm{m} \mathrm{s}^{-1}\right]$ & - & - & - & - & - \\
\hline Shear wave velocity $\left[\mathrm{m} \mathrm{s}^{-1}\right]$ & - & - & - & - & - \\
\hline \multicolumn{6}{|l|}{10543 - schist } \\
\hline Bulk density $\left[\mathrm{g} \mathrm{cm}^{-3}\right]$ & - & - & - & - & - \\
\hline Grain density $\left[\mathrm{g} \mathrm{cm}^{-3}\right]$ & - & - & - & - & - \\
\hline Porosity $[\%]$ & - & - & - & - & - \\
\hline Thermal conductivity $\left[\mathrm{W} \mathrm{m}^{-1} \mathrm{~K}^{-1}\right.$ ] & 2.00 & 2.03 & 2.01 & 0.02 & 2 \\
\hline Thermal diffusivity $\left[\times 10^{-6} \mathrm{~m}^{2} \mathrm{~s}^{-1}\right]$ & 1.00 & 1.00 & 1.00 & 0.00 & 2 \\
\hline Compressional wave velocity $\left[\mathrm{m} \mathrm{s}^{-1}\right]$ & - & - & - & - & - \\
\hline Shear wave velocity $\left[\mathrm{m} \mathrm{s}^{-1}\right]$ & - & - & - & - & - \\
\hline
\end{tabular}


Table 4. Continued.

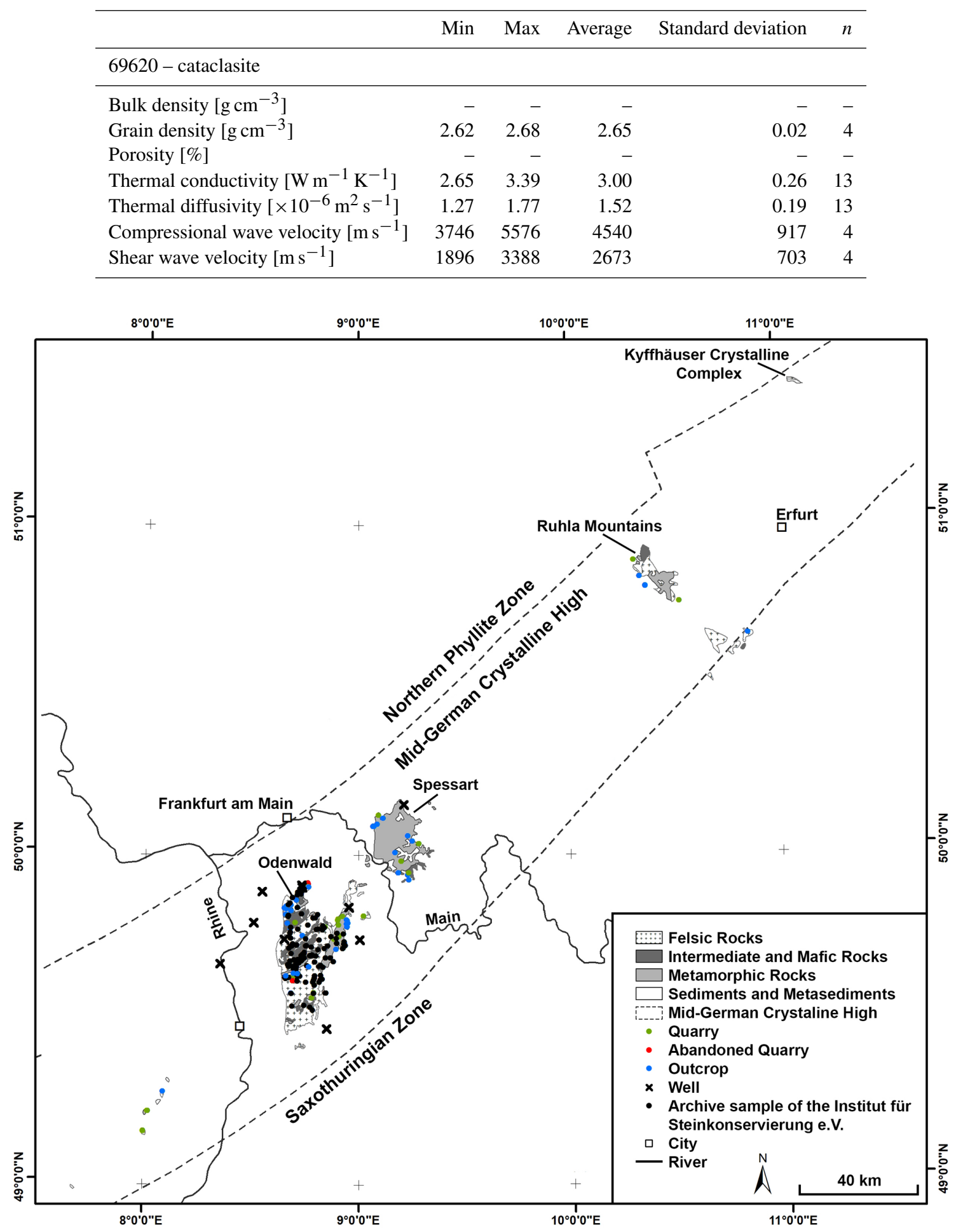

Figure 3. Sampling location of the presented database scattered around Odenwald, Spessart and the Ruhla Mountains as well as well locations and outcrops in the Palatinate Forest. Simplified overview map (after Hirschmann, 1995; Voges et al., 1993; Klügel, 1997; Kroner et al., 2008) of the Mid-German Crystalline Rise outcrops. Sampling locations are from Bär (2008, 2012), Biewer (2017), Dutheillet de Lamothe (2016), Hoffmann (2015), Klaeske (2010), Lambert (2016), Maire (2014), Pei (2009), Rüther (2011), Schäffer (2012), Schäffer et al. (2018), Vogel (2016), Weber (2014), Welsch (2012) and Welsch et al. (2015). 

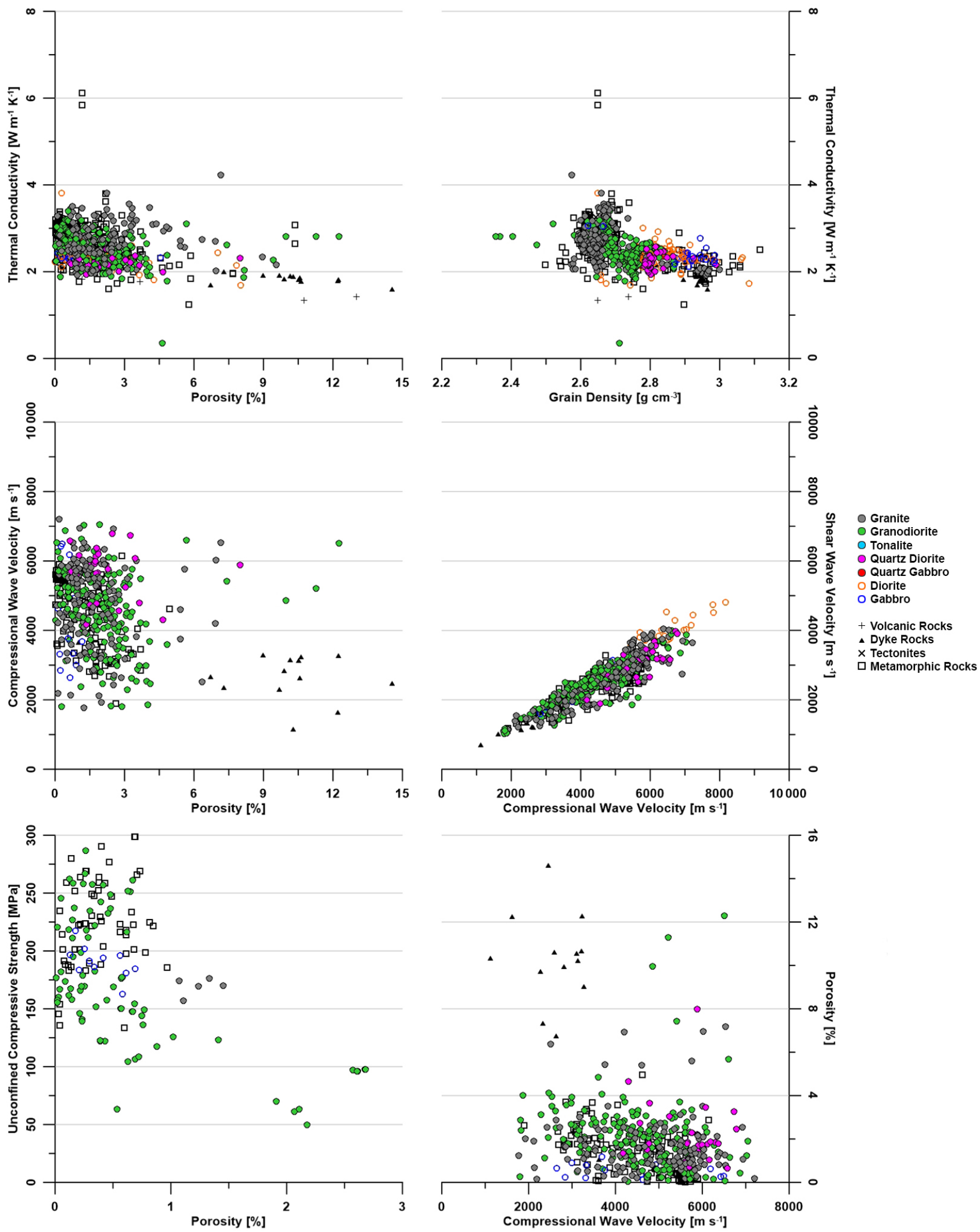

Figure 4. Scatter plots of the most common petrophysical properties of the dataset of Weinert et al. (2020b). 
für Steinkonservierung" (column "outcrop type") were sampled in their archive, and it may be possible to request the samples directly at the Institut für Steinkonservierung e.V. In the case of well samples, please refer to the Hessian Agency for Nature Conservation, Environment and Geology. For samples of the Weiterstadt 1, Worms 3 and Stockstadt 33R wells, please refer to the Bundesverband Erdgas, Erdöl und Geoenergie e.V.

\section{Discussion}

The compilation of comprehensive databases always requires critical review of the input data. Often, published data do not match the minimum requirements of the dataset (as, e.g. mentioned in Bär et al., 2020). All data stored in the presented database were measured at the same institution applying the same methods. Therefore, all data presented conform to the same standards and quality requirements. This also ensures a high comparability of the measurements since the methodological accuracy and errors are identical throughout the dataset. Due to the coherence of the presented dataset, the documented properties are easy to correlate and can help to understand petrophysical properties within the Mid-German Crystalline Rise but also allow deriving general correlations between petrophysical properties (e.g. Fig. 4).

The described correlations and data ranges are also in good agreement with previous studies of rock of the MidGerman Crystalline Rise (e.g. Kushnir et al., 2018) as well as crystalline basement rocks of various different locations (e.g. Carmichael, 1989, and references therein; Mielke et al., 2017; Kushnir et al., 2018), e.g. the Gonghe Basin Complex (Weinert et al., 2020a). The correlations of porosity against thermal conductivity as well as the compressional wave velocity are in accordance with findings of Mielke et al. (2017). Decreasing compressional wave velocities with increasing porosities are in accordance with findings of, e.g. Kushnir et al. (2018) or Weinert et al. (2020a). The same negative correlation is found for porosity and unconfined compressive strength (e.g. the presented dataset; Li and Aubertin, 2003; Kushnir et al., 2018; Weinert et al., 2020a).

The metadata attached to each measurement and specimen are advantageous to many other databases. Therefore, petrophysical properties can easily be extracted and applied in other studies or for parametrization of local to regional numerical models. Nonetheless, the presented data may need to be individually processed (e.g. upscaled) to fit applications such as large-scale geothermal modelling. Such data processing can be required since the presented data only represent laboratory-scale matrix properties. Such small-scale data may vary significantly in larger rock masses. Such scale effects are most prominently observed on matrix and bulk permeabilities. Matrix permeabilities (or permeabilities measured in the laboratory) commonly underestimate the bulk reservoir permeability (as data of, e.g. Stober and Jodocy, 2009, or Vidal and Genter, 2018, suggest) due to neglecting permeability of any fractures or fracture network.
Datasets such as those provided by Achtziger-Zupančič et al. (2017) and Scibek (2020) can provide valuable information for reservoir-scale permeability estimations also in nearfield areas of fault zones. Manning and Ingebritsen (1999), Ingebritsen and Manning (2010) and Stober and Bucher (2015) published data on reservoir-scale permeabilities of the upper crust which can be used for assessing and upscaling matrix permeabilities as provided in the presented database. In general, a variety of different upscaling methods are developed, applied and reviewed (e.g. Wen and GómezHernández, 1996; Farmer, 2002; Qi and Hesketh, 2005). Techniques can be as simple as applying power-law averages on a representative elementary volume (e.g. Qi and Hesketh, 2005) but can also require the integration of a fracture network model (e.g. Bao et al., 2012). Since the published methods for upscaling petrophysical properties are plentiful, a close consideration of the applied processes is necessary. The method always needs to be chosen regarding the researched application, rock type or geological setting.

Author contributions. SW and KB conceptualized the study. SW collected samples, performed rock physical analysis and wrote the manuscript with contributions from all authors. KB compiled archive measurements, contributed to the fieldwork and sampling in archives, and acquired the funding. IS contributed to archive sampling. All authors read and approved the final paper.

Competing interests. The authors declare that they have no conflict of interest.

Acknowledgements. The authors thank Karin Kraus from the Institut für Steinkonservierung e.V. for providing their archive samples for analysis. Further, the authors are thankful to the Bundesverband Erdgas, Erdöl und Geoenergie e.V. (BVEG) as well as BEB Erdgas und Erdöl GmbH \& Co. KG, the owner of the wells, for providing core samples of the crystalline basement for investigation and publishing. The authors also thank the Hessian Agency for Nature Conservation, Environment and Geology (HLNUG), especially Johann-Gerhard Fritsche, as well as Gerald Gabriel from the Leibniz Institute for Applied Geophysics (LIAG) and Sonja Wedmann from the Senkenberg Research Institute and Natural History Museum for providing access to the well cores.

As research assistants, Alexander Lambert, Christian Schneider and Stina Krombach helped in measuring the presented data. The authors are further thankful for the help of Florent Dutheillet de Lamothe within the framework of his internship at Technical University of Darmstadt. Also, the authors are grateful for contributions of Bianca Vogel, Alexander Lambert, Rafael Schäffer, Helmuth Hoffmann, Romain Maire, Alexej Philipp, Johanna Rüther, Jan Niklas Weger, Ulrike Klaeske, Liang Pei and Hendrik Biewer in the framework of their conducted student theses.

Furthermore, the authors thank for the financial support by the DFG in the framework of the Excellence Initiative, Darmstadt Graduate School of Excellence Energy Science and Engineering 
(GSC 1070) as well as the Federal Ministry for Economic Affairs and Energy for financing the present research in the scope of Hessen 3D 2.0 (grant no. 0325944A).

Financial support. This research has been supported by the Bundesministerium für Wirtschaft und Energie (grant no. 0325944A) and the Deutsche Forschungsgemeinschaft (grant no. GSC 1070).

Review statement. This paper was edited by Kirsten Elger and reviewed by two anonymous referees.

\section{References}

Achtziger-Zupančič, P., Loew, S., and Mariéthoz, G.: A new global database to improve predictions of permeability distribution in crystalline rocks at site scale, J. Geophys. Res.-Sol. Ea., 122, 3513-3539, https://doi.org/10.1002/2017JB014106, 2017.

Aretz, A., Bär, K., Götz, A. E., and Sass, I.: Outcrop analogue study of Permocarboniferous geothermal sandstone reservoir formations (northern Upper Rhine Graben, Germany): impact of mineral content, depositional environment and diagenesis on petrophysical properties, Int. J. Earth Sci., 105, 1431-1452, https://doi.org/10.1007/s00531-015-1263-2, 2016.

Anthes, G. and Reischmann, T.: Timing of granitoid magmatism in the eastern mid-German crystalline rise, J. Geodyn., 31, 119143, https://doi.org/10.1016/S0264-3707(00)00024-7, 2001.

ASTM International: D3148 Standard test method for elastic moduli of intact rock core specimens in uniaxial compression, ASTM International, West Conshohocken, PA, https://doi.org/10.1520/D3148-02, 2002.

ASTM International: D2664-04 Standard test method for triaxial compressive strength of undrained rock core specimens without pore pressure measurements, ASTM International, West Conshohocken, PA, https://doi.org/10.1520/D2664-04, 2004.

ASTM International: D7012-14e1 Standard test methods for compressive strength and elastic moduli of intact rock core specimens under varying states of stress and temperatures, ASTM International, West Conshohocken, PA, https://doi.org/10.1520/D701214E01, 2014.

ASTM International: D3967-16 Standard test method for splitting tensile strength of intact rock core specimens, ASTM International, West Conshohocken, PA, https://doi.org/10.1520/D396716, 2016.

Bao, K., Salama, A., and Sun, S.: Upscaling of permeability field of fractured rock systems: Numerical examples, J. Appl. Math., 2012, 546203, https://doi.org/10.1155/2012/546203, 2012.

Bär, K. M.: 3D-Modellierung des tiefengeothermischen Potenzials des nördlichen Oberrheingrabens und Untersuchung der geothermischen Eigenschaften des Rotliegend, Diploma thesis, Technical University of Darmstadt, 2008 (in German with English abstract).

Bär, K. M.: Untersuchung der tiefengeothermischen Potenziale von Hessen. PhD Thesis, Technical University of Darmstadt, available at: https://tuprints.ulb.tu-darmstadt.de/3067/, 2012 (in German with English abstract).
Bär, K. and Mielke, P.: Stratigraphic classification table (Stratigraphy): $\mathrm{P}^{3}$ - Stratigraphy. V. 1.0, GFZ Data Services, Potsdam, https://doi.org/10.5880/GFZ.4.8.2019.P3.s, 2019.

Bär, K., Mielke, P., and Knorz, K.: Petrographic classification table (Petrography): $\mathrm{P}^{3}$ - Petrography. V. 1.0, GFZ Data Services, Potsdam, https://doi.org/10.5880/GFZ.4.8.2019.P3.p, 2019.

Bär, K., Reinsch, T., and Bott, J.: The PetroPhysical Property Database (P3) - a global compilation of lab-measured rock properties, Earth Syst. Sci. Data, 12, 2485-2515, https://doi.org/10.5194/essd-12-2485-2020, 2020.

Biewer, H.: Vergleich von Eigenschaften petrothermaler Reservoirgesteine des Gonghe-Beckens und TrommGranits/Weschnitz-Plutons, Master Thesis, Technical University of Darmstadt,2017 (in German with English abstract).

Brätz, H.: Radiometrische Altersdatierung und geochemische Untersuchung von Orthogneisen, Graniten und Granitporphyren aus dem Ruhlaer Kristallin, Mitteldeutsche Kristallinzone, PhD Thesis, Bayerische Julius-Maximilians-Universität Würzburg, 2000 (in German).

Buntebart, G.: Geothermics - An introduction, Springer-Verlag Berlin Heidelberg, 1984.

Carmicheal, R. S.: Practical Handbook of physical properties of rocks and minerals, CRC Press, Boca Raton, 1989.

Cohen, K. M., Finney, S. C., Gibbard, R. L., and Fan, J.-X.: The ICS International Chronistratigraphic Chart, episodes, 36, 199204, 2013.

Deutscher Bundestag: Drucksache 15/1835,15, Wahlperiode 24.10.2003, Bericht des Ausschusses für Bildung, Forschung und Technikfolgenabschätzung (17. Ausschuss) gemäß $§ 56 a$ der Geschäftsordnung. Technikfolgenabschätzung: Monitoring Möglichkeiten geothermischer Stromerzeugung in Deutschland, 2003 (in German).

Dombrowsky, A., Henjes-Kunst, F., Höhndorf, A., Kröner, A., Okrusch, M., and Richter, O.: Orthogneisses in the Spessart Crystalline Complex, Northwest Bavaria: Witnesses of Silurian granitoids magmatism at an active continental margin, Geol. Rundsch., 84, 399-411, https://doi.org/10.1007/BF00260449, 1995.

Dutheillet de Lamothe, F.: Petrophysical characterization or rocks and correlation of these properties with geochemical and mineralogical composition, Internship Report, Technical University of Darmstadt, 2016.

Farmer, C. L.: Upscaling: a review, Int. J. Numer. Meth. Fl., Int. J. Numer. Meth. Fl., 40, 63-78, https://doi.org/10.1002/fld.267, 2002.

Filomena, C. M., Hornung, J., and Stollhofen, H.: Assessing accuracy of gas-driven permeability measurements: a comparative study of diverse Hassler-cell and probe permeameter devices, Solid Earth, 5, 1-11, https://doi.org/10.5194/se-5-1-2014, 2014.

Hirschmann, G.: Lithological characteristics (Mid-German Crystalline Rise), in: Pre-Permian geology of Central and Eastern Europe, edited by: Dallmeyer, R. D., Franke, F., and Weber, K., Springer Verlag, Berlin, 155-163, 1995.

Hoffmann, H.: Petrophysikalische Eigenschaften der Mitteldeutschen Kristallinschwelle im Bereich des Oberrheingrabens, Master Thesis, Technical University of Darmstadt, 2015 (in German with English abstract).

Howell, J. A., Martinius, A. W., and Good, T. R.: The application of outcrop analogues in geological modelling: a review, present status and future outlook, in: Sediment-Body 
geometry and heterogeneity: Analogue studies for modelling the subsurface, Geol. Soc. Spec. Pub., London, 387, 1-25, https://doi.org/10.1144/SP387.12, 2014

Ingebritsen, S. E. and Manning, C. E.: Permeability of the continental crust: dynamic variations inferred from seismicity and metamorphism, Geofluids, 10, 193-205, https://doi.org/10.1111/j.1468-8123.2010.00278.x, 2010.

Kirsch, H., Kober, B., and Lippolt, H. J.: Age of intrusion and rapid cooling of the Frankenstein gabbro (Odenwald, SW-Germany) evidence by ${ }^{40} \mathrm{Ar} /{ }^{39} \mathrm{Ar}$ and single zircon ${ }^{207} \mathrm{~Pb} /{ }^{206} \mathrm{~Pb}$ measurements, Geol. Rundsch. 77, 693-711, https://doi.org/10.1007/BF01830178, 1988.

Klaeske, U.: Bestimmung des geothermischen Potenzials des Kristallinen Odenwaldes, Bsc Thesis, Technical University of Darmstadt, 2010 (in German with English abstract).

Klinkenberg, L. J.: The permeability of porous media to liquids and gases, Drilling Production Practice, New York, API-41-200, 1941.

Klügel, T.: Geometrie und Kinematrik einer variszischen Plattengrenze. Der Südrand des Rhenoherzynikums im Taunus, Geologische Abhandlungen Hessen, 101, 215 pp., ISBN 9783895318030, 1997 (in German).

Krietsch, H., Doetsch, J., Dutler, N., Jalali, M., Gischig, V., Loew, S., and Amann, F.: Comprehensive geological dataset describing a crystalline rock mass for hydraulic stimulation experiments, Nat. Sci. Data, 5, 180269, https://doi.org/10.1038/sdata.2018.269, 2018.

Kroner, U., Mansy, J.-L. Mazur, S., Aleksandrowsky, P., Hann, H. P., Huckriede, H., Lacquement, F., Lamarche, J., Ledru, P., Pharaoh, T. C., Zedler, H., Zeh, A., and Zulauf, G.: Variscan tectonic, in: The geology of Central Europe. Volume 1: Precambrian and Palaeozoic, edited by: McCann, T. Geological Society, London, 599-664, 2008.

Kushnir, A. R. L., Heap, M. J., Baud, P., Gilg, H. A., Reuschlé, T., Lerouge, C., Dezayes, C., and Duringer, P.: Characterizing the physical properties of rocks from the Paleozoic to Permo-Triassic transition in the Upper Rhine Graben, Geotherm. Energ., 6, 16, https://doi.org/10.1186/s40517-018-0103-6, 2018.

Lambert, A.-D.: Bestimmung der petrophysikalischen und felsmechanischen Kennwerte des Tromm- und WeschnitzPlutons, Odenwald, Deutschland, Bsc Thesis, Technical University of Darmstadt, 2016 (in German with English abstract).

Li, L. and Aubertin, M.: A general relationship between porosity and uniaxial strength of engineering materials, Can. J. Civ. Eng., 30, 644-658, https://doi.org/10.1139/103-012, 2003.

Linnemann, U., Romer, R. L., Pin, C., Aleksandrowsky, P., Bula, Z., Geisler, T., Kachlik, V., Krzeminska, E., Mazur, S., Motuza, G., Murphy, J. B., Nance, R. D., Pisarevsky, S. A., Schulz, B., Ulrich, J., Wiszniewska, J., Zaba, J., and Zeh, A.: Precambrian, in: The geology of Central Europe. Volume 1: Precambrian and Palaeozoic, edited by: McCann, T., Geological Society, London, 21-102, 2008.

Lippolt, H. J.: Nachweis altpaläozoischer Primäralter (Rb$\mathrm{Sr})$ und karbonischer Abkühlalter (K-Ar) der MuskovitBiotit-Gneise des Spessarts und der Biotit-Gneise des Böllsteiner Odenwaldes, Geol. Rundsch., 75, 569-583, https://doi.org/10.1007/BF01820632, 1986 (in German).
Machek, M., Roxerová, Z., Janoušek, V., Staněk, M., Petrovský, and E. René, M.: Petrophysical and geochemical constraints on alteration processes in granites, Stud. Geophys. Geod., 57, 710 740, https://doi.org/10.1007/s11200-013-0923-6, 2013.

Maire, R.: Investigation of thermo-physical and mechanical parameters of crystalline geothermal reservoir rocks of the Upper Rhine Graben (Germany), Master thesis, LaSalle Beauvais, Technical University of Darmstadt, 2014.

Manning, C. E. and Ingebritsen, S. E.: Permeability of the continental crust: implications of geothermal data and metamorphic systems, Rev. Geophyis., 37, 127-150, https://doi.org/10.1029/1998RG900002, 1999.

McCann, T.: The geology of Central Europe. Volume 1: Precambrian and Palaeozoic, Geological Society, London, 2008.

Mielke, P., Weinert, S., Bignall, G., and Sass, I.: Thermophysical rock properties of greywacke basement rock and intrusive lavas from the Taupo Volcanic Zone, New Zealand, J. Volcanol. Geoth. Res., 324, 179-189, https://doi.org/10.1016/j.jvolgeores.2016.06.002, 2016.

Mielke, P., Bär, K., and Sass, I.: Determining the relationship of thermal conductivity and compressional wave velocity of common rock types as a basis for reservoir characterization, J. Appl. Geophys., 140, 135-144, https://doi.org/10.1016/j.jappgeo.2017.04.002, 2017.

Mutschler, T.: Neufassung der Empfehlung Nr.1 des Arbeitskreises Versuchstechnik Fels der Deutschen Gesellschaft für Geotechnik e.V.: Einaxiale Druckversuche an zylindrischen Gesteinsprüfkörpern, Bautechnik, 81, 825-834, https://doi.org/10.1002/bate.200490194, 2004.

Okrusch, M.: The Spessart crystalline complex, Northwest Bavaria, DMG SFMC Joint Meeting 1983, Excursion E4, Fortschritte der Mineralogie, 61, Beiheft 2, 135-169, 1983 (in German).

Pei, L.: Analysis of initiation and propagation of hydraulically induced fracture, Master thesis, Technical University of Darmstadt, 2009.

Popov, Y. A., Pribnow, D. F. C., Sass, J. H., Williams, C. F., and Burkhardt, H.: Characterization of rock thermal conductivity by high resolution optical scanning, Geothermics. 28, 253-276, https://doi.org/10.1016/S0375-6505(99)00007-3, 1999.

Qi, D. and Hesketh, T.: An analysis of upscaling techniques for reservoir simulation, Petr. Sci. Technol., 23, 827-842, https://doi.org/10.1081/LFT-200033132, 2005.

Reischmann, T., Anthes, G., Jaeckel, P., and Altenberger, U.: Age and origin oft he Böllsteiner Odenwald, Miner. Petrol., 72, 2944, https://doi.org/10.1007/s007100170025, 2001.

Rüther, J.: Thermofazielle Interpretation des Permokarbons im Sprendlinger Horst, Diploma thesis, Technical University of Darmstadt, 2011 (in German with English abstract).

Sass, I., Weinert, S., and Bär, K.: Success rates of petroleum and geothermal wells and their impact on the European geothermal industry, Swiss Bull. Angew. Geol. 21, 54-65, https://doi.org/10.5169/seals-658197, 2016.

Schäffer, R.: Hydrogeologische und geothermische Untersuchungen der Heilquellen und Heilbrunnen Bad Soden-Salmünsters. Diploma Thesis, Technical University of Darmstadt, 2012 (in German with English abstract).

Schäffer, R., Bär, K., and Sass, I.: Multimethod exploration of the hydrothermal reservoir in Baden Soden- 
Salmünster, Germany, Z. Dtsch. Ges. Geowiss., 169, 311-333, https://doi.org/10.1127/zdgg/2018/0147, 2018.

Scibek, J.: Multidisciplinary database of permeability of fault zones and surrounding protolith rocks at world-wide sites, Sci. Data, 7, 95, https://doi.org/10.1038/s41597-020-0435-5, 2020.

Stein, E.: The geology of the Odenwald Crystalline Complex, Minera. Petr., 72, 7-28, https://doi.org/10.1007/s007100170024, 2001.

Stober, I. and Bucher, K.: Hydraulic conductivity of fractured upper crust: insights from hydraulic tests in boreholes and fluid-rock interaction in crystalline basement rocks, Geofluids, 15, 161-178, https://doi.org/10.1111/gfl.12104, 2015.

Stober, I. and Jodocy, M.: Eigenschaften geothermischer Nutzhorizonte im baden-württembergischen und französischen Teil des Oberrheingrabens, Grundwasser, 14, 127-137, https://doi.org/10.1007/s00767-009-0103-3, 2009.

Timmerman, M. J.: Palaezoic magmatism, in: The geology of Central Europe. Volume 1: Precambrian and Palaeozoic, edited by: McCann, T. Geological Society, London, 665-748, 2008.

Todt, W. A., Altenberger, U., and Raumer, J. F.: U-Pb data on zicrons for the thermal peak of metamorphism in the Variscan Odenwald, Germany, Geol. Rundsch., 84, 466-472, https://doi.org/10.1007/BF00284514, 1995 (in German).

Ukar, E., Laubach, S. E., and Hooker, J. N.: Outcrops as guides to subsurface natural fractures: Example from the Nikanassin Formation tight-gas sandstone, Grande Cache, Alberta foothills, Canada, Mar. Petrol. Geol., 103, 255-275, https://doi.org/10.1016/j.marpetgeo.2019.01.039, 2019.

Vidal, J. and Genter, A.: Overview of naturally permeable fractured reservoirs in the central and southern Upper Rhine Graben: Insights from geothermal wells, Geothermics, 74, 5773, https://doi.org/10.1016/j.geothermics.2018.02.003, 2018.

Vogel, B. C.: Petrophysikalische und felsmechanische Untersuchung kristalliner Gesteine des Weschnitz-Plutons, Bsc thesis, Technical University of Darmstadt, 2016 (in German with English abstract).

Voges, A., Toloczyki, M., Trurnit, P., and Wittekindt, H.: Geologiesche Karte der Bundesrepublik Deutschland 1:1.000.000, BGR, Hannover, 1993.

Weber, J. N.: Geothermische Aufschlussanalyse des Steinbruches Mainzer Berg, östlich von Darmstadt, Bsc thesis, Technical University of Darmstadt, 2014 (in German with English abstract).
Weinert, S., Bär, K., and Sass, I.: Thermophysical rock properties of the crystalline Gonghe Basin Complex (Northeastern QinghaiTibet-Plateau, China) basement rocks, Environ. Earth Sci., 79, 2020a.

Weinert, S., Bär, K., and Sass, I.: Petrophysical Properties of the Mid-German Crystalline High: A Database for Bavarian, Hessian, Rhineland-Palatinate and Thuringian Outcrops, TUdatalib, https://doi.org/10.25534/tudatalib-278, 2020b.

Welsch, B.: Forschungsbohrung Heubach: Untersuchungen zu den geothermischen Reservoireigenschaften des Odenwald Kristallins. Diploma Thesis, Technical University of Darmstadt (in German with English abstract), 2012.

Welsch, B., Baer, K., Schulte, D., Rühaak, W., and Chauhan, S.: Simulation und Evaluierung von Kopplungs- und Speicherkonzepten regenerativer Energieformen zur Heizwärmeversorgung, Final report, Technical University of Darmstadt, 2015 (in German with English abstract).

Wen, X.-H. and Gómez-Hernández, J. J.: Upscaling hydraulic conductivities in heterogeneous media: An overview, J. Hydrogeol., 183, xi-xxxii, https://doi.org/10.1016/S0022-1694(96)80030-8, 1996.

Weydt, L. M., Ramírez-Guzmán, Á. A., Pola, A., Lepillier, B., Kummerow, J., Mandrone, G., Comina, C., Deb, P., Norini, G., Gonzalez-Partida, E., Avellán, D. R., Macías, J. L., Bär, K., and Sass, I.: Petrophysical and mechanical rock property database of the Los Humeros and Acoculco geothermal fields (Mexico), Earth Syst. Sci. Data, 13, 571-598, https://doi.org/10.5194/essd13-571-2021, 2021.

Will, T., M. and Schmädicke, E.: A first report of eclogites in the Odenwald Crystalline Complex: evidence for highpressure metamorphism in the Mid-German Crystalline Rise, Germany, Lithos, 59, 109-125, https://doi.org/10.1016/S00244937(01)00059-7, 2001.

Zeh, A. and Wunderlich, J.: Mitteldeutsche Kristallinzone, in: Geologie von Thüringen, edited by: Seidel, G., E. Schweitzbart'sche Verlagsbuchhandlung, Stuttgart, 24-51, 2003.

Zeh, A., Williams, I. S., Brätz, H., and Millar, I. L.: Different age response of zircon and monazite during the tectonometamorphic evolution of a high grade paragneiss from the Ruhla Crystalline Complex, Central Germany, Contrib. Miner. Petr., 145, 691-709, https://doi.org/10.1007/s00410-003-0462-1, 2003. 